\title{
INTERNATIONAL MIGRATION IN ASIA AND THE PACIFIC
}

\section{DETERMINANTS AND ROLE OF ECONOMIC INTEGRATION}

Aiko Kikkawa, Raymond Gaspar, and Cyn-Young Park

NO. 592

October 2019
ADB ECONOMICS WORKING PAPER SERIES 


\section{ADB Economics Working Paper Series}

\section{International Migration in Asia and the Pacific Determinants and Role of Economic Integration}

Aiko Kikkawa, Raymond Gaspar, and Cyn-Young Park

No. 592 | October 2019
Aiko Kikkawa (atakenaka@adb.org) is economist, Raymond Gaspar (rgaspar.consultant@adb.org) is consultant, and Cyn-Young Park (cypark@adb.org) is director at the Economic Research and Regional Cooperation Department, Asian Development Bank.

The authors thank Yasuyuki Sawada, Kenichi Ando, Masahiro Kawai, as well as the participants of the two ERINA International Workshops "Toward Northeast Asian Economic Integration" held in Niigata on 29 January 2018 and in Tokyo, Japan, on 6-7 September 2018 for helpful comments and suggestions. They also acknowledge Concepcion Latoja, Paul Mariano, and Mara Tayag for excellent research assistance. 
(C) 2019 Asian Development Bank

6 ADB Avenue, Mandaluyong City, 1550 Metro Manila, Philippines

Tel +632632 4444; Fax +6326362444

www.adb.org

Some rights reserved. Published in 2019.

ISSN 2313-6537 (print), 2313-6545 (electronic)

Publication Stock No. WPS190473-2

DOI: http://dx.doi.org/10.22617/WPS190473-2

The views expressed in this publication are those of the authors and do not necessarily reflect the views and policies of the Asian Development Bank (ADB) or its Board of Governors or the governments they represent.

ADB does not guarantee the accuracy of the data included in this publication and accepts no responsibility for any consequence of their use. The mention of specific companies or products of manufacturers does not imply that they are endorsed or recommended by ADB in preference to others of a similar nature that are not mentioned.

By making any designation of or reference to a particular territory or geographic area, or by using the term "country" in this document, $A D B$ does not intend to make any judgments as to the legal or other status of any territory or area.

This work is available under the Creative Commons Attribution 3.0 IGO license (CC BY 3.0 IGO)

https://creativecommons.org/licenses/by/3.0/igo/. By using the content of this publication, you agree to be bound by the terms of this license. For attribution, translations, adaptations, and permissions, please read the provisions and terms of use at https://www.adb.org/terms-use\#openaccess.

This CC license does not apply to non-ADB copyright materials in this publication. If the material is attributed to another source, please contact the copyright owner or publisher of that source for permission to reproduce it. $\mathrm{ADB}$ cannot be held liable for any claims that arise as a result of your use of the material.

Please contact pubsmarketing@adb.org if you have questions or comments with respect to content, or if you wish to obtain copyright permission for your intended use that does not fall within these terms, or for permission to use the ADB logo.

Corrigenda to ADB publications may be found at http://www.adb.org/publications/corrigenda.

Notes:

In this publication, " $\$$ ” refers to United States dollars.

ADB recognizes "Hong Kong" as Hong Kong, China and "Korea" as the Republic of Korea.

The ADB Economics Working Paper Series presents data, information, and/or findings from ongoing research and studies to encourage exchange of ideas and to elicit comment and feedback about development issues in Asia and the Pacific. Since papers in this series are intended for quick and easy dissemination, the content may or may not be fully edited and may later be modified for final publication. 


\section{CONTENTS}

TABLES AND FIGURES

ABSTRACT $v$ V

$\begin{array}{ll}\text { I. INTRODUCTION } & 1\end{array}$

II. INTERNATIONAL AND INTERREGIONAL MIGRATION IN ASIA AND THE PACIFIC 1

III. DETERMINANTS OF INTERNATIONAL MIGRATION AND MOVEMENT OF LABOR 4

A. $\quad$ Factors Driving Movement of People 4

B. $\quad$ Migration and Economic Integration 6

IV. $\quad$ EMPIRICALANALYSIS

A. $\quad$ Methods and Data 6

B. Determinants of International Labor Migration from Asia 10

C. Cross-Border Migration and Economic Integration: Substitute or Complement? 12

D. Robustness Checks 14

V. FUTURE MIGRATION FLOWS IN AND FROM ASIA AND THE PACIFIC

A. Demographic Changes and Population Aging $\quad 15$

B. International Migration of the Skilled Workforce 16

VI. CONCLUSIONS AND POLICY IMPLICATIONS

$\begin{array}{ll}\text { APPENDIX } & 19\end{array}$

$\begin{array}{lr}\text { REFERENCES } & 27\end{array}$ 


\section{TABLES AND FIGURES}

\section{TABLES}

$1 \quad$ Drivers of International Labor Migration from and within Asia 11

2 Asian Regional and Global Migration and Trade 12

3 Asian Regional and Global Migration and Foreign Direct Investment 13

$4 \quad$ Asian Regional and Global Migration and Regional Production Networks 13

$5 \quad$ Registered Nurses in Singapore by Citizenship, 2010 and 2016

A1 Generalized Estimating Equation Estimates of the Gravity Model of Migration 19

A2.1 Baseline and Full Results-Trade and Migration 20

A2.2 Baseline and Full Results-Foreign Direct Investment and Migration 21

A2.3 Baseline and Full Results-Global Value Chains and Migration 22

A3.1 Robustness-Determinants of Migration 23

A3.2 Robustness-Trade and Migration $\quad 24$

A3.3 Robustness-Foreign Direct Investment and Migration $\quad 25$

A3.4 Robustness-Global Value Chains and Migration 26

\section{FIGURES}

$1 \quad$ Stock of International Migrants to and from Asia and the Pacific, 1990-2017 2

2 International Migrant Stock and the Population Share, 2017

3 International Migrant Stock and Share of Migrants from Asia, 1990-2017 4

4 Changes in Working-Age Populations, 2017-2040 15

5 Educational Attainment of Working-Age Population 17 


\begin{abstract}
International migration is an essential element of economic integration. Yet, the intraregional movement of people and labor in Asia and the Pacific has stagnated in recent years even as the flow of goods, services, and investment have steadily risen. This paper examines key factors driving the movement of people from and within the region using bilateral international migrant stock data. Our analysis shows that commonly known determinants such as income differences; population size; and political, geographical, and cultural proximities between the migrant source and destination countries are associated with greater movement, along with the growing share of older population in destination economies and the similarities in the level of educational attainment. The paper also finds that crossborder migration is affected, in varied directions, by the degree of economic integration between the source and destination economies, especially through bilateral trade and value chain links. The offshoring of production-and hence jobs and other economic opportunities - to migrant source countries suppresses outmigration, but the expected rise in the source country income will eventually promote migration by relaxing financial constraints.
\end{abstract}

Keywords: international migration, labor mobility, regional economic integration

JEL codes: F22, $\mathrm{O} 15$ 


\section{INTRODUCTION}

According to standard economic theories, the free movement of people contributes to the efficient and productive use of labor and human capital and helps catalyze the transfer of knowledge and skills, which generate dynamic efficiencies. Within Asia and the Pacific, efforts to encourage labor mobility are gaining importance-especially in attracting, retaining, and circulating professional workers-as many economies transition to more skills-based and knowledge-intensive industries. In addition, the region has much to gain from facilitating labor mobility given the expectation of widening labor supply and demand mismatches associated with rapidly aging populations in some countries.

Yet experience shows that the mobility of people in Asia lags when compared to advances in goods, services, and foreign investment. Between 2001 and 2017, the intraregional share of trade in Asia stayed high and grew further from $53 \%$ to $58 \%$, and that of foreign direct investment (FDI) rose from $47 \%$ to $50 \%$. In contrast, the intraregional share of the international migration during the same period declined from 43\% to 35\% (ADB 2018). Trade and investment and the buildup of the regional value chains over the past 2 decades could have made movement of labor and natural resources redundant (Ducanes and Abella 2008).

Against this backdrop, this paper examines patterns and key determinants of movement of people from and within Asia and the Pacific, and explores the association between international migration and the degree of economic integration measured by the flows of goods and investments. Our analysis, based on bilateral international migrant stock data, finds that cross-border migration is affected, in both positive and negative directions, by the degree of economic integration between the source and destination economies, especially through bilateral trade and value chain links. The offshoring of production-and hence jobs and other economic opportunities-to migrant source countries suppresses outmigration, but the expected rise in the source country income will eventually promote migration by relaxing financial constraints. The study also finds that commonly known determinants of movement such as income differences; population size; and political, geographical, and cultural proximities between the migrant source and destination countries are important drivers of migration in the region and that growing share of older population in destination economies and the similarities in the level of educational attainment trigger more migration.

The next section presents the trends and patterns of international migration in the region followed by the empirical analysis identifying the determinants of international migration both within and from the region. The analysis will be carried out in two steps. First, based on the literature, we select known contributors to the movement of people and evaluate the effects on migration within Asia and then Asia to world. We then incorporate economic integration indicators as covariates to examine the additive effects. The future direction of the international migration and the policy implications in the region are discussed in the remaining sections.

\section{INTERNATIONAL AND INTERREGIONAL MIGRATION IN ASIA AND THE PACIFIC}

Over a third of international migrants worldwide in 2017 (258 million) originate from Asia and the Pacific, making the region the largest source. International migrants from the region almost doubled

International migrants are defined as "persons who have ever changed their country of usual residence, that is to say, persons who have spent at least one year of their lives in a country other than the one in which they live at the time the data are gathered" (United Nations 1998, para. 185). The international migrants stock therefore consists of people crossing borders for reasons such as employment, family reunification, study, and fleeing from conflict and violence. In some instances, the creation of new borders generates a large stock of international migrants-as during the fallout from the collapse of the Soviet Union. 
from 48.3 million in 1990 to 86.9 million in 2017 (Figure 1). In 2017, India had the most outmigrants with 17 million, followed by the People's Republic of China (PRC) with 10 million. The growth of migration from India and the PRC is notable-in 1990, the emigrant stock of India was just 6.7 million and in the PRC it was 4.2 million. Other key source countries in the region in 2017 are Bangladesh (7.5 million), Pakistan ( 6 million), and the Philippines (5.7 million).

Figure 1: Stock of International Migrants to and from Asia and the Pacific, 1990-2017

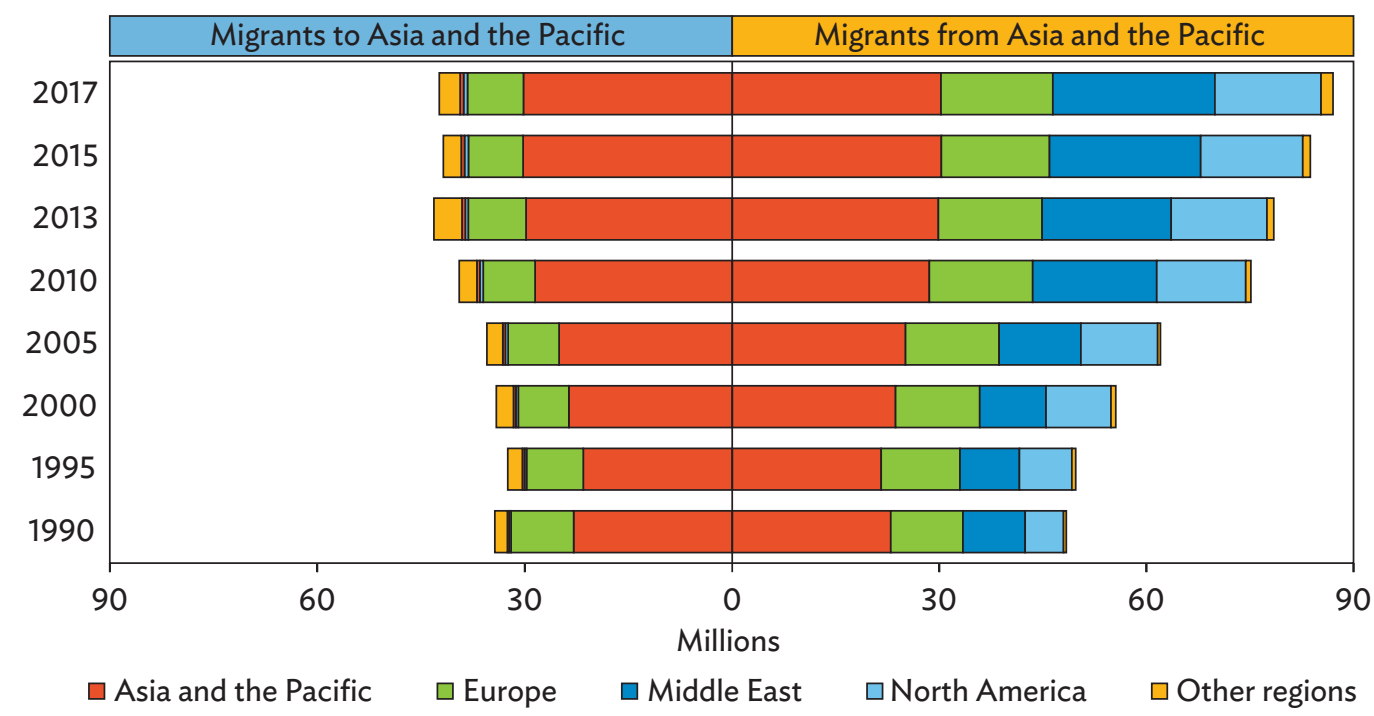

Source: ADB calculations using data from United Nations, Department of Social and Economics Affairs. International Migrant Stock: The 2017 Revision. http://www.un.org/en/development/desa/population/migration/data/estimates2/estimates17.shtml (accessed August 2018).

Meanwhile, the total number of migrants residing in Asia and the Pacific stood at 42.4 million in 2017, about 71\% of whom came from economies within the region. Figure 2 shows the biggest host economies of Asian migrants, which include Australia (7 million); India (5 million); Thailand (3.5 million); Pakistan (3.4 million); and Hong Kong, China (2.7 million). ${ }^{2}$ Some of these cross-border movements resulted from the birth of new nations and borders (like the case of many migrants from neighboring countries in India) and displacements due to conflicts (e.g., refugees from Afghanistan hosted in Pakistan). They also reflect more recent movement of the workforce in the region. For example, Thailand now hosts a few million migrant workers from neighboring countries, including Myanmar.

2 Pakistan hosts the largest number of refugees, totaling 1.85 million at end 2017, in the region. They are mainly from Afghanistan (UNHCR Population Statistics. http://popstats.unhcr.org/en/overview\#_ga=2.171769312.1130396316.153128835434172564.1531288354 [accessed August 2018]). 
Figure 2: International Migrant Stock and the Population Share, 2017

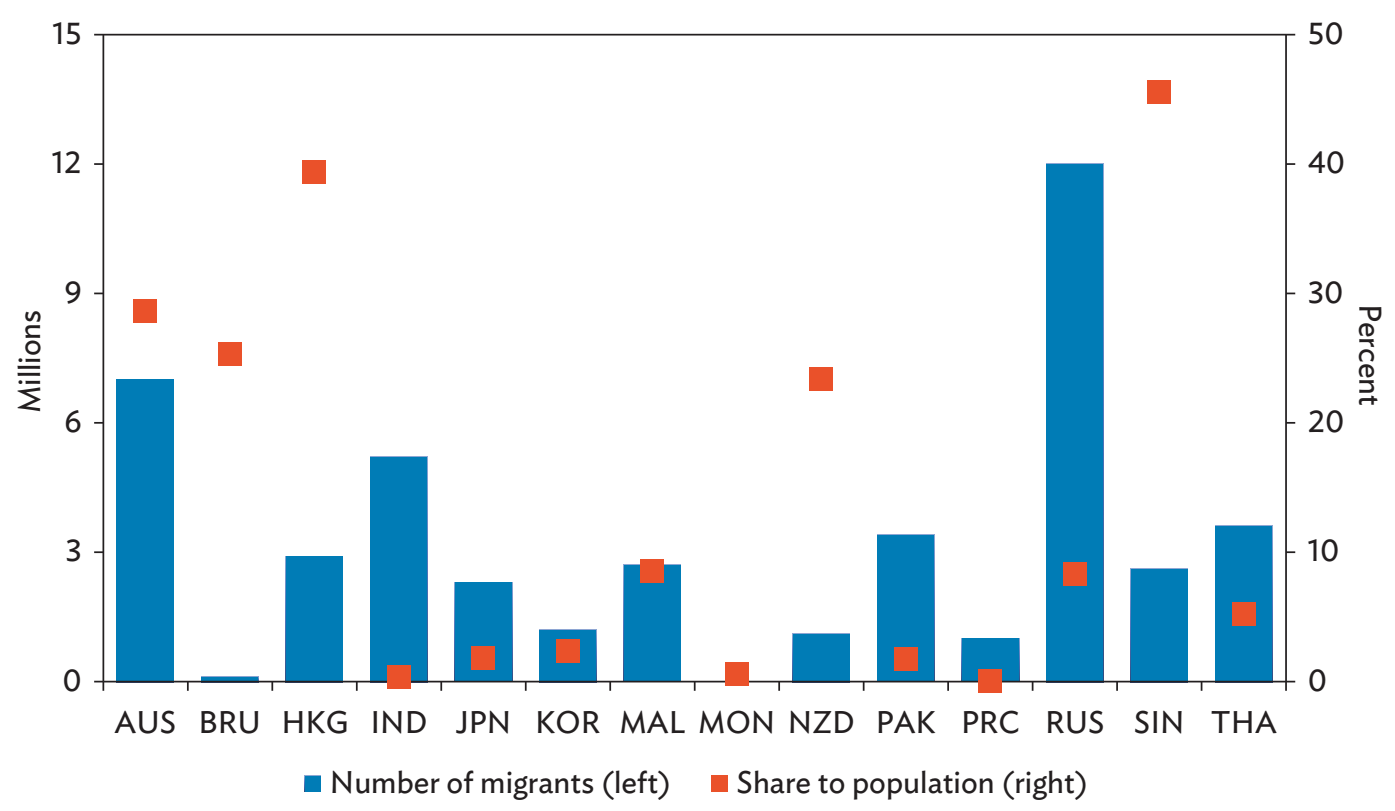

AUS = Australia; BRU = Brunei Darussalam; HKG = Hong Kong, China; IND = India; JPN = Japan; MAL = Malaysia; MON = Mongolia; NZD = New Zealand; PAK = Pakistan; PRC = People's Republic of China; KOR = Republic of Korea; RUS = Russian Federation; SIN = Singapore; THA = Thailand.

Source: ADB calculations using data from United Nations, Department of Economic and Social Affairs.

http://www.un.org/en/development/desa/population/ (accessed July 2018); and United Nations Department of Economic and Social Affairs. International Migrant Stock: The 2017 Revision.

http://www.un.org/en/development/desa/population/migration/data/estimates2/estimates17.shtml (accessed August 2018).

The recent pattern of international migration is increasingly driven by the movement of labor, largely in anticipation of higher wages, better benefits, and career opportunities. The International Labour Organization (2015) estimated that about 89\% of international migrants were over the age of 15 , of which $72 \%$ were migrant workers. In Asia and the Pacific, the share of migrant workers is likely higher than the global average, mainly due to the large outflow of temporary and nonfamily migration to the Middle East and Southeast Asian destinations. That is also likely, given that opportunities for settlement and family reunification are restricted in these destinations, and looser rules would otherwise lead to an increase in the share of nonworking international migrants.

Some economies in the region such as Australia and New Zealand have long operated open immigration for family reunification and employment, leading to high shares of international migrants, at over $20 \%$ of their populations (Figure 2). Singapore (46\%) and Hong Kong, China (39.2\%) are also densely populated with migrant workers and foreign residents.

While many regional economies remain hosts for most Asian migrants, intraregional migration has declined over the years. The 30.2 million Asian migrants hosted within the region in 2017 constitute only $34.7 \%$ of total outmigration from the region, a steep drop from $47.5 \%$ in 1990 (Figure 3). In contrast, other regions now host greater number of Asian migrants. The proportion of Asian outmigration to the Middle East increased sharply from 17.3\% (9.6 million) in 1990 to 26.9\% (23.4 million) in 2017. There were also increases in migration to Europe (from 12.2 million to 
16.2 million) and to North America (from 9.4 million to 15.4 million). Middle Eastern destinations that offer mass temporary employment opportunities for skilled and unskilled workers appear more attractive than Asian destinations, while other destinations offer skilled migration opportunities with higher pay and the possibility of permanent settlement.

Figure 3: International Migrant Stock and Share of Migrants from Asia, 1990-2017

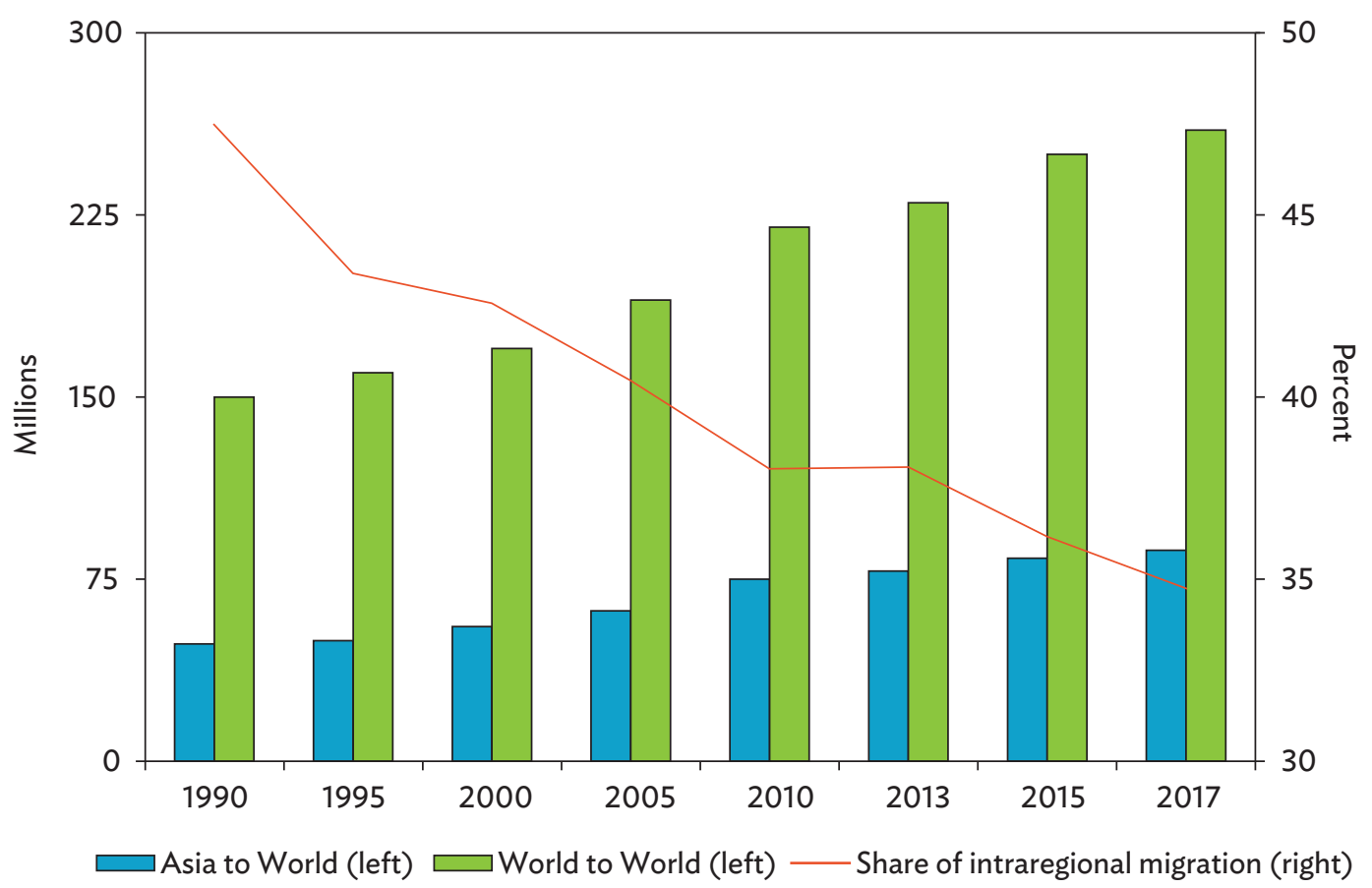

Source: ADB calculations using data from United Nations, Department of Economic and Social Affairs. International Migrant Stock: The 2017 Revision. http://www.un.org/en/development/desa/population/migration/data/estimates2/estimates17.shtml (accessed August 2018).

\section{DETERMINANTS OF INTERNATIONAL MIGRATION AND MOVEMENT OF LABOR}

\section{A. Factors Driving Movement of People}

Migration is triggered by a wide array of factors ranging from social, economic, and demographic structures to individual preferences. At the macro or cross-country level, the gravity framework-a common tool in international trade analysis-remains widely used to identify factors influencing international migration. The framework assumes, as with goods and capital, that the movement of people mostly takes place in geographical, political, and cultural proximities because short distance, common borders and languages, and historical relationships can reduce the financial and psychological costs of migration. Sharing a language or cultural ties can reduce the transaction costs associated with accessing information on jobs and social amenities, for example. These factors also often lead to the formation of migration networks and diaspora communities within destination countries, which then invite subsequent waves of migration through job referrals and family reunifications (McKenzie and Rapoport 2010, Massey and Zenteno 1999). Some of the largest regional migratory flows can be 
explained by such proximities (e.g., Mekong country migration mainly to Thailand, and Indonesians moving to Malaysia).

Besides structural factors, migration is an individual decision based on perceived costs and benefits. Incomes in source and destination countries along with labor market conditions influence the decision to migrate (Clemens 2014, World Bank 2018). In principle, the wider the income gap between source and destination countries the higher the incentive to migrate. However, rising incomes in source countries alone can also drive migration as they allow more people to afford the upfront costs of migrating (Martin and Taylor 1996). Persistent unemployment and low availability of employment benefits also help explain such movements since they influence the anticipated net gain from migrating. Empirical assessment of the impact of labor-related factors on migration remains challenging, however, since migrant workers are often placed in labor markets that are segmented from the locals.

Population size in the source and destination countries can jointly determine the scale of migration, while demographic trends can alter the volume of demand and supply of migrants (Zaiceva and Zimmermann 2014). Kim and Cohen (2010), in their analysis of migration flows to a selection of advanced countries, validate the strong influence of source and destination countries' population sizes in absorbing and sending migrants. A study by Dao et al. (2018), based on nearly a half century of migration data across the world, finds that demographic factors govern migratory flows and exert greater influence than socioeconomic factors. Advanced economies drawing significant shares of migrants of Asian origin are facing population aging and reviewing and revising their immigration systems to recruit more migrant workers in health and care services, domestic work, construction, and knowledge-intensive sectors. ${ }^{3}$ Meanwhile, the rapidly growing youth workforce in migrant source countries in Asia is said to exert pressure toward outmigration, especially amid high unemployment among educated youth, though their chances of migrating for work depend on the availability of suitable jobs in destination countries.

Whether the quality of human capital and the skill level of the workforce in source and destination countries determine the volume of bilateral migration remain an empirical question. In their pioneering work on the brain drain literature, Stark, Helmenstein, and Prskawetz (1998) presented a model encompassing the incentive to improve human capital in a developing country of origin and the prospect of employment in a developed country. If most of the jobs available for migrants are unskilled, increasing the quality of human capital in a source country may reduce migration: educated workers may be less interested in taking jobs abroad. In the case of skilled migration, the narrowing of skill gaps between source and destination countries may lead to more migration, though the total number may be much smaller than the stream of unskilled workers. In recent years, the surge in migration among high-skilled labor has become more evident. Labor migrants holding tertiary education are estimated to have accounted for nearly half of migrants in 2010, up from only $27 \%$ in 1990 (World Bank 2018). It is therefore worthwhile to understand how changes in relative skills among countries influenced migratory flows in the past, primarily attempting to examine whether migrants complemented or substituted the local workforce.

3 Demographic trends are different in major migrant destination countries in the Middle East, where populations are relatively young and still growing fast. 


\section{B. Migration and Economic Integration}

The degree of economic integration and interconnectedness between and among countries through trade, direct investment, or the production network (value chains) can, in principle, influence the mobility of people and labor through multiple pathways. Standard trade theory suggests that trade acts as a substitute to migration by equalizing factor prices between the economies involved. Additional jobs generated by FDI could keep workers at home. Sauvant, Mallampally, and Economou (1993) argued that FDI reduces incentives to migrate in the short term, through employment, and in the long term, by way of improvements in economic growth and welfare. These arguments are thought to have led to the promotion of the North American Free Trade Agreement in discouraging further movement of Mexicans to the north. In their study on Mexico-US migration, Aroca and Maloney (2005) estimated at most a 2\% drop in Mexican migrant flows to the US in response to doubling of FDI inflows from the US.

A growing body of evidence, however, shows a potential complementarity between FDI, trade, and migration. A positive relationship between migration and trade arises when income growth in a less developed country is generated when trade with a more economically developed partner relaxes financial constraints, and-as noted earlier in this paper-allows more people to migrate. Gould (1994) emphasized the importance of the business links that arise from immigration. Bahar and Rapoport (2018) provided evidence that migration promotes knowledge diffusion and so leads to trade diversification. De Simone and Manchin (2012) found that migrant networks substantially reduce information asymmetry for exporters and investors, leading to more transactions. Complementarity between skilled migration and FDI exists in the long term through the diaspora network effect (Kugler and Rapoport 2011, Tomohara 2017, Shin and Moon 2018).

\section{EMPIRICAL ANALYSIS}

\section{A. Methods and Data}

We evaluate the determinants of international migration in and from Asia and the implication of economic integration in two steps. First, we examine whether the social, economic, and demographic factors described in section III.A indeed influence the patterns of Asian migration, using historical bilateral international migration stock data. Second, we add some indicators of economic integration to the baseline regression to evaluate the additive effect on mobility.

Our first empirical model follows the standard gravity model below:

$$
\begin{gathered}
\text { Migration }_{i j t}=\alpha+\beta_{1} \text { Economic }_{i j t}+\beta_{2} \text { Demographic }_{i j t}+ \\
\beta_{3} \text { Skills }_{i j t}+\beta_{4} \text { Gravity }_{i j}+\theta_{i}+\omega_{j}+\delta_{t}+\varepsilon_{i j t}
\end{gathered}
$$

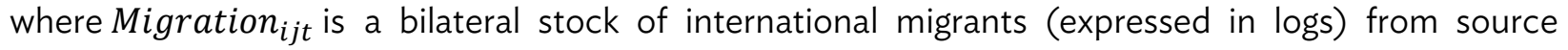
country $i$ to destination country $j$ in year $t$. The stock of international migrants is taken from the UN Population Division of the Department of Economic and Social Affairs, with data available in 5-year intervals from 1950 to 2015. The UN data report migrant stocks and related information from most member countries and territories but the quality of data varies across countries. To overcome any estimation bias arising from measurement discrepancies in reporting formats of migrant stocks across 
countries, migration routes involving less than 500 migrants are excluded. ${ }^{4}$ To capture the forces driving international labor (hence economic) migration, the stock of refugee population from the migrant stocks is subtracted. ${ }^{5}$

Aligned with existing empirical works, migration determinants are categorized into four general forces: (i) Economic $_{i j t}$, (ii) Demographic $c_{i j t}$, (iii) Skills $_{i j t}$, and (iv) Gravity $i j$. Economic Evt $_{i j t}$ variables such as per capita gross domestic product (GDP) of source economies and income gap (calculated as the difference in the log of per capita GDP of the destination-source pairs) are from the World Development Indicators database of the World Bank. These variables attempt to capture how economic conditions and differences in development levels and economic opportunities influence international migration from Asia and the Pacific. While wages and labor market conditions were worth considering, these details were not used because they were not available, both for many of ADB developing member countries and in earlier periods.

Demographic $_{i j t}$ includes the total population (in logs) in source and destination economies, which controls for country size, indicating capacity to send or receive international migrants, and oldage dependency ratios of destination economies. The old-age dependency ratio in destination economies is added to try to capture how aging is shaping the migration pattern from the region. The growing number of elders in destination countries is expected to draw migration, alongside the growing youth population in developing Asian economies. Data are sourced from the latest revision of the UN World Population Prospects. Population data are adjusted by deducting the total number of international migrants from the respective countries.

To empirically assess whether the human capital and skills level of source and destination countries affect the migration pattern in Asia, Skills $s_{i j t}$ is incorporated in the model. Without constraints to labor migration and differences in qualifications, and where available jobs for migrants predominantly require low-skilled labor, improvement in human capital and skills in source economies may reduce migration. The opposite can be expected when opportunities are open for skilled labor. Therefore, the skills gap is seen as one of the strong forces in international migration. This variable is measured as the difference in average years of schooling of population ages 15 and over between the destination and source economies. The Barro and Lee (2013) dataset on educational attainment is used, which is available in 5-year intervals from 1950 to 2010, with projected educational attainment from Barro and Lee (2015) supplying missing information for the period 2011-2015.

4 Some countries report on major migration routes only, leaving other bilateral migration information empty, while others provide comprehensive information.

5 While refugees and labor migrants face similar factors, the weights given by each group to specific factors in deciding to move may differ significantly. In a policy report, the World Bank (2018) found evidence that geographic forces shape the distribution of refugees more than economic factors, while the opposite is found for international migrants overall. Nonetheless, the main results remain unchanged with or without a refugee stock. 
Gravity $_{i j}$ is a vector of dyadic variables such as distances between capitals, contiguity (shared borders), common official languages, and colonial relationships that attempt to capture the economic and psychological costs associated with international migration. Intuitively, closer bilateral routes tend to have lower transportation costs which, among other factors, allow people to move with ease. Common primary and official languages and strong historical ties facilitate migration by way of networks and assimilation within migrant communities. Data for this are sourced from the Centre d'Etudes Prospectives et d'Informations Internationales. ${ }^{6}$

To control for unobservable time-invariant characteristics that may affect international migration patterns, $\theta_{i}$ and $\omega_{j}$ are added, referring to the source country and the destination country fixed effects, along with time dummies, $\delta_{t}$, to account for time-variant effects. All parameters are estimated using the ordinary least squares (OLS) method with cluster-robust standard errors. Fixed effects (exploiting within-bilateral migration route variation) and generalized estimating equations (GEE) provide alternative and robust estimates that control for unobserved heterogeneity and bilateral specific correlation outcome variables in the model. ${ }^{7}$

The analysis focuses on migration from Asia and the Pacific to major global destinations (Route 1: Asia to World) and within Asia (Route 2: Asia to Asia). Based largely on data availability, the empirical analysis is conducted on bilateral stock of migrants from 26 ADB developing members in Asia plus the Russian Federation ${ }^{8}$ to 30 major destination economies ${ }^{9}$ (Route 1 ). This route involves 433 source-destination country pairs in six 5 -year intervals. These major destination economies host more than $80 \%$ of the total Asian outmigrants. Intra-Asia migration (Route 2) in 12 major destination economies in Asia and the Pacific involves 147 unbalanced panel migration routes.

\section{Evaluating the Trade-Foreign Direct Investment-Migration Link}

To gain insight into the relationship between international migration and the degree of economic integration between the source and destination countries, equation (1) is extended in two variants (Model 1 and 2), adding separately as regressors the bilateral specific variables measuring: (i) trade, (ii) investment, and (iii) cross-border production chain links. Model 1 evaluates the overall relationship between migratory flow and integration variables, while Model 2 gives a crude measure of the indirect income channel that may explain the link. The second model makes it necessary to

\footnotetext{
Gravity data can be downloaded from the following link: http://www.cepii.fr/CEPII/en/bdd_modele/presentation.asp?id=8.

Among the strand of GEE specifications, an exchangeable working correlation structure is used, based on the Quasilikelihood under independence model criterion test as in Cui and Qian (2007). The GEE approach would effectively resolve potential bias associated with bilateral-specific correlations of outcome variables within the panel over the period of observations. Horrocks (1997) noted that failure to consider the correlation existing within the panel invalidates the standard errors of the parameter estimates. Hanley et al. (2003) noted that the GEE method of parameter estimation is more efficient for statistical hypothesis testing involving correlated panel data and several binary responses, in which the study includes the gravity variables of contiguity, colonial relationship, and common language.

8 These include Armenia; Bangladesh; Brunei Darussalam; Cambodia; Fiji; Hong Kong, China; India; Indonesia; Kazakhstan; the Kyrgyz Republic; the Lao People's Democratic Republic; Malaysia; Maldives; Myanmar; Mongolia; Nepal; Pakistan; the People's Republic of China; the Philippines; the Republic of Korea; the Russian Federation; Singapore; Sri Lanka; Tajikistan; Thailand; and Viet Nam.

9 These include Armenia; Australia; Bahrain; Canada; France; Germany; Greece; Hong Kong, China; Israel; Italy; Japan; Kuwait; Malaysia; Nepal; the Netherlands; New Zealand; Oman, the People's Republic of China; Qatar; the Republic of Korea; the Russian Federation; Saudi Arabia; Singapore; Spain; Sweden; Thailand; Ukraine; the United Arab Emirates; the United Kingdom; and the US.
} 
use an interaction term of integration variables and per capita GDP of Asian source economies. The extended model is estimated using fixed effects and GEE for robustness. An advantage of the fixed effect technique is that it does not require the assumption of no correlation between the timeinvariant dyadic variables with the unobservable heterogeneity, as it does for OLS estimations. Despite estimating no coefficients for time-invariant dyadic gravity components, the fixed effect estimation flexibly accounts for the unobserved time-varying variables that influence bilateral migration routes in different ways.

The depth of the trade link is given by the value of bilateral merchandise trade (exports plus imports) expressed as a percentage of source economy GDP. Bilateral merchandise trade (in millions of US dollars), summing exports and imports, are sourced from the International Monetary Fund's Direction of Trade Statistics. Contemporaneous 5-year interval information is gathered from 1990 to 2015 in line with the bilateral migration stock data. Investment link is measured by the net bilateral FDI flows (in \$ millions) from the destination country, expressed as the share to source country's GDP. ${ }^{10}$ Net bilateral FDI flows to source economies refer to the consolidated FDI using available sources such as United Nations Conference on Trade and Development, Association of Southeeast Asian Nations, Eurostat, and various national reports. The extent of international production sharing is measured by the foreign value added embedded in exports (simply, vertical specialization) of the source country from the destination country, expressed as percentage of the source country's total gross exports." Limited data availability in earlier periods and in some ADB developing member countries produces a substantial loss in the number of observations; therefore, samples to carry out the analysis vary with that of the baseline model.

The intention of the analysis is to examine the presence of a statistically significant association between the scale of the bilateral migrant stock and prevailing determinants based on existing literature, which does not confirm a causal relationship. Likewise, other determinants of international labor migration, for which data availability remain a challenge, should be noted. For example, immigration policy regimes and changes-particularly related to labor migration-in destination economies that shape and redirect cross-border migration. ${ }^{12}$ The influence of quality of life measures in destination economies is another variable not captured in the model, although use of the income gap may solve part of this. Last but not least, given that the analysis involves only international migration from ADB's developing member economies to selected locations, it does not consider the interplay with supply and demand from other regions, which could be alternative destinations for migrants.

10 Following the 5-year dataset of bilateral migration, the 5-year average is derived for net FDI flows in source economies.

11 It is available in various years: 2000, 2005, 2008, 2011-2017. To be consistent with the bilateral migration data, 5-year interval information is used for 2000, 2005, and 2015. The information in 2011 is an alternative for the missing 2010 data, noting little variation expected in annual terms. This information is available from the ADB's Statistical Database System: https://sdbs.adb.org/sdbs/jsp/GVC/GVCLanding.jsp.

12 For example, that of Ruhs (2018), or the DEMIG POLICY data compiled by the International Migration Institute of the University of Oxford either cover a limited number of destination countries in Asia or do not come in sufficient time series. 


\section{B. Determinants of International Labor Migration from Asia}

Table 1 presents estimates of equation (1) evaluating the determinants of international labor migration from Asia to the World (Route 1) and within Asia (Route 2) based on the OLS and fixed effect models. The results validate the strong influence of economic factors in shaping international migration from Asia. As predicted, the income gap between destination and source countries, measured by respective real per capita GDP, is positively associated with the volume of bilateral migration. Elasticity of the income gap to migration is higher for within Asia migration. If the income gap widens by $10 \%$, intraregional migration can be expected to increase by about $6 \%$, while the elasticity in Asia to world migration is lower, at $2 \%-4 \%$ depending on the specification. The estimates also reveal a positive relationship between international labor migration and income levels in source countries in Asia, which generally supports the idea that rising incomes in source economies help reduce financial constraints and so encourage migration.

The results also offer insights on the significant influence of population size and ongoing demographic trends. Theoretically consistent, larger countries opt to receive more migrants, while smaller developing economies tend to send more (Hanson 2008). It is interesting to note that the influence of country size in Asian migration flow is almost proportional in Route 1, with Route 2 even exhibiting an elasticity of above 1 . These results suggest significant migration flow from Asia, considering that it amounts to about a third of global migration volumes.

The results also show how aging shapes Asian labor migration. Using old-age dependency ratios to capture the interplay of the older and working-age population, estimates show an almost 5\% increase in migration stock from Asia given a 1 percentage point increase in the ratio (other factors constant). It is even higher for intra-Asian migration, at 6.5\%. The rapid population aging experienced in major destination economies, especially in Asia, is expected to further drive migration due to the region's demographic diversity. Many source countries in Southeast and South Asia continue to enjoy a demographic dividend. Population aging can also contribute to making public opinion more open to immigration (Nakata 2017).

The estimates in this paper also provide an insight into the likely role that improvement in human capital among source countries can play in the region's migration activities. Earlier in the section, two possible scenarios were provided for how the skills gap could either drive or stymie migration, which depends heavily on the skills requirements in relevant sectors from destination economies and the compatibility of education and skills between source and destination countries. The results indicate that the larger the skills gap, the smaller the migrant stock. This points to great potential for source countries whose workforces are acquiring more education and training to meet the demand for skilled workers abroad (conditional on other factors such as immigration policies).

Consistent with standard gravity models of international migration, variables indicating geographic distance and cultural and historical proximity explain cross-border movement at a large margin. As expected, greater bilateral distances record lower migration, while contiguity tends to be associated with more migration. It comes as no surprise that higher migration is seen where sourcedestination countries have a common official or primary language and a colonial relationship. These factors not only reduce the direct and indirect costs of initial migration but also help migrants assimilate. Estimates from GEE also generate findings similar to the baseline estimates from pooled OLS and fixed effects models (Appendix Table A1). 
Table 1: Drivers of International Labor Migration from and within Asia

\begin{tabular}{|c|c|c|c|c|}
\hline \multirow[b]{2}{*}{ Variables } & \multicolumn{2}{|c|}{ Baseline } & \multicolumn{2}{|c|}{ With Bilateral FE } \\
\hline & $\begin{array}{c}\text { Route } 1 \\
\text { (Asia to World) }\end{array}$ & $\begin{array}{c}\text { Route } 2 \\
\text { (Asia to Asia) }\end{array}$ & $\begin{array}{c}\text { Route } 1 \\
\text { (Asia to World) }\end{array}$ & $\begin{array}{c}\text { Route } 2 \\
\text { (Asia to Asia) }\end{array}$ \\
\hline \multicolumn{5}{|l|}{ Economic factors } \\
\hline $\begin{array}{l}\text { Income gap between source and destination } \\
\text { economies }\end{array}$ & $\begin{array}{r}0.401^{* * *} \\
(0.148)\end{array}$ & $\begin{array}{l}0.648^{* *} \\
(0.267)\end{array}$ & $\begin{array}{l}0.240^{* * *} \\
(0.063)\end{array}$ & $\begin{array}{r}0.583^{* * *} \\
(0.114)\end{array}$ \\
\hline $\begin{array}{l}\text { Real per capita GDP in source economies, } \\
\text { in logs }\end{array}$ & $\begin{array}{l}0.421^{* *} \\
(0.183)\end{array}$ & $\begin{array}{r}0.874^{* * *} \\
(0.334)\end{array}$ & $\begin{array}{l}0.283^{* * *} \\
(0.078)\end{array}$ & $\begin{array}{r}0.807^{* * *} \\
(0.151)\end{array}$ \\
\hline \multicolumn{5}{|l|}{ Demographic factors } \\
\hline $\begin{array}{l}\text { Total population in destination economies, in } \\
\text { logs }\end{array}$ & $\begin{array}{l}0.923^{* * *} \\
(0.249)\end{array}$ & $\begin{array}{l}2.042^{* *} \\
(0.966)\end{array}$ & $\begin{array}{l}1.113^{* * *} \\
(0.115)\end{array}$ & $\begin{array}{l}1.957^{* * *} \\
(0.462)\end{array}$ \\
\hline Total population in source economies, in logs & $\begin{array}{r}0.056 \\
(0.347)\end{array}$ & $\begin{array}{l}-0.285 \\
(0.509)\end{array}$ & $\begin{array}{l}-0.411^{* *} \\
(0.163)\end{array}$ & $\begin{array}{l}-0.283 \\
(0.306)\end{array}$ \\
\hline $\begin{array}{l}\text { Old-age dependency ratio in destination } \\
\text { economies }\end{array}$ & $\begin{array}{l}0.046^{* * *} \\
(0.008)\end{array}$ & $\begin{array}{r}0.065^{* * *} \\
(0.012)\end{array}$ & $\begin{array}{l}0.055^{* * *} \\
(0.005)\end{array}$ & $\begin{array}{l}0.065^{* * *} \\
(0.009)\end{array}$ \\
\hline \multicolumn{5}{|l|}{ Skills complementarity } \\
\hline $\begin{array}{l}\text { Gap between source and destination } \\
\text { economies in average years of schooling }\end{array}$ & $\begin{array}{l}-0.510^{* *} \\
(0.202)\end{array}$ & $\begin{array}{l}-0.556^{*} \\
(0.283)\end{array}$ & $\begin{array}{r}-0.589^{* * *} \\
(0.099)\end{array}$ & $\begin{array}{r}-0.970^{* * *} \\
(0.164)\end{array}$ \\
\hline \multicolumn{5}{|l|}{ Gravity variables } \\
\hline Distance between capitals, in logs & $\begin{array}{r}-1.520^{* * *} \\
(0.149)\end{array}$ & $\begin{array}{r}-1.375^{* * *} \\
(0.264)\end{array}$ & & \\
\hline Contiguity & $\begin{array}{l}1.039^{* *} \\
(0.427)\end{array}$ & $\begin{array}{l}0.848^{*} \\
(0.486)\end{array}$ & & \\
\hline Common official or primary language & $\begin{array}{l}0.707^{* * *} \\
(0.240)\end{array}$ & $\begin{array}{l}0.609^{*} \\
(0.337)\end{array}$ & & \\
\hline Colonial relationship & $\begin{array}{r}2.682^{* * *} \\
(0.263)\end{array}$ & $\begin{array}{l}1.739^{* * *} \\
(0.530)\end{array}$ & & \\
\hline Constant & $\begin{array}{r}3.891 \\
(6.667)\end{array}$ & $\begin{array}{r}-13.270 \\
(16.295)\end{array}$ & $\begin{array}{l}-5.918^{*} \\
(3.443)\end{array}$ & $\begin{array}{r}-26.517^{* * *} \\
(9.055)\end{array}$ \\
\hline Year dummies & Yes & Yes & Yes & Yes \\
\hline Source country FE & Yes & Yes & Yes & Yes \\
\hline Destination country FE & Yes & Yes & Yes & Yes \\
\hline Source-destination country FE & No & No & Yes & Yes \\
\hline Number of observations & 2,276 & 816 & 2,276 & 816 \\
\hline R-squared & 0.639 & 0.634 & 0.475 & 0.512 \\
\hline Number of bilateral routes & & & 433 & 147 \\
\hline
\end{tabular}

$\mathrm{FE}=$ fixed effects, GDP = gross domestic product, $\mathrm{OLS}=$ ordinary least squares. Notes: Robust standard errors in parentheses. ${ }^{* *} p<0.01,{ }^{* *} p<0.05,{ }^{*} p<0.1$.

Source: Authors' estimates. 


\section{Cross-Border Migration and Economic Integration: Substitute or Complement?}

Tables 2-4 present the fixed effect estimates of the coefficients evaluating the link between economic integration and international migration from and within Asia (Routes 1 and 2). This is achieved by evaluating the overall effect (Model 1) and its pathways (Model 2). ${ }^{13}$ The depth of trade ties between source and destination countries is found to substitute and complement migration depending on the pathways, with overall (net) positive impact on the size of bilateral migrant stock (Table 2). The results are consistent with the hypothesis that enhanced trade links reduce migration motives on one hand, and push more flows on the back of rising per capita income, and hence financial capacity to migrate in countries of origin on the other. Such pattern holds strongly on overall migration flows from Asia and less on the intra-Asian movement, which explains the large net positive coefficient in Route 2 from the first model.

Table 2: Asian Regional and Global Migration and Trade

\begin{tabular}{lrrrrrr}
\hline \multirow{2}{*}{ Variables } & \multicolumn{2}{c}{ Model 1 } & & \multicolumn{2}{c}{ Model 2 } \\
\cline { 2 - 3 } \cline { 5 - 6 } Bilateral trade (\% of GDP) & Route 1 & Route 2 & & Route 1 & Route 2 \\
Interaction with (log) real per capita GDP in source & $0.030^{* * *}$ & $0.036^{* * *}$ & & $-0.043^{* *}$ & -0.019 \\
economies & $(0.003)$ & $(0.004)$ & & $(0.018)$ & $(0.028)$ \\
Year dummies & & & & $0.008^{* * *}$ & $0.005^{*}$ \\
Source country FE & & & & $(0.002)$ & $(0.003)$ \\
Destination country FE & Yes & Yes & & Yes & Yes \\
Source-destination country FE & Yes & Yes & Yes & Yes \\
Number of observations & Yes & Yes & Yes & Yes \\
R-squared & Yes & Yes & & Yes & Yes \\
Number of bilateral routes & 2,200 & 803 & 2,200 & 803 \\
\hline
\end{tabular}

$\mathrm{FE}=$ fixed effects, $\mathrm{GDP}=$ gross domestic product.

Notes: Similar set of regressors from the baseline model as well as a constant term are included in the estimation, but are not reported. Standard errors in parentheses. ${ }^{* *} p<0.01,{ }^{* *} p<0.05,{ }^{*} p<0.1$.

Source: Authors' estimates.

In contrast, results using FDI or value chain links do not indicate decisive trends in the association. Tables 3 and 4 suggest that the cross-border investment or value chains themselves may not have a direct impact, but that the impact is expressed through the trade channel. One interesting observation is that the degree of integration in the production network and the supply chain between source and destination economies is found to have a strong substitution effect in intraregional migration. This intuitively explains the relatively low rate of intraregional share of migration in the region, which boasts strong regional value chain networks.

13 Regression outcomes of all variables are reported in Appendix Tables A2.1-A2.3, along with results using the alternative estimation (GEE). They are largely consistent with fixed effects estimates. 
Table 3: Asian Regional and Global Migration and Foreign Direct Investment

\begin{tabular}{lccccc}
\hline \multirow{2}{*}{ Variables } & \multicolumn{2}{c}{ Model 1 } & & \multicolumn{2}{c}{ Model 2 } \\
\cline { 2 - 3 } \cline { 5 - 6 } Net bilateral foreign direct investment (\% of GDP) & Route 1 & Route 2 & & Route 1 & Route 2 \\
\cline { 5 - 6 } & 0.014 & 0.030 & & -0.075 & -0.086 \\
Interaction with (log) real per capita GDP in source & $(0.016)$ & $(0.022)$ & & $(0.069)$ & $(0.087)$ \\
economies & & & 0.011 & 0.015 \\
\hline Year dummies & & & & $(0.008)$ & $(0.011)$ \\
Source country FE & Yes & Yes & Yes & Yes \\
Destination country FE & Yes & Yes & Yes & Yes \\
Source-destination country FE & Yes & Yes & Yes & Yes \\
Number of observations & Yes & Yes & Yes & Yes \\
R-squared & 1,013 & 373 & 1,013 & 373 \\
Number of bilateral routes & 0.513 & 0.457 & 0.514 & 0.461 \\
\hline
\end{tabular}

$\mathrm{FE}=$ fixed effects, GDP = gross domestic product.

Notes: Similar set of regressors from the baseline model as well as a constant term are included in the estimation, but are not reported. Standard errors in parentheses. ${ }^{* *} p<0.01,{ }^{* *} p<0.05,{ }^{*} p<0.1$

Source: Authors' estimates.

\section{Table 4: Asian Regional and Global Migration and Regional Production Networks}

\begin{tabular}{lcccc}
\hline & \multicolumn{2}{c}{ Model 1 } & \multicolumn{2}{c}{ Model 2 } \\
\cline { 2 - 5 } Variables & Route 1 & Route 2 & Route 1 & Route 2 \\
\hline Bilateral vertical specialization (\% of gross exports) & -0.007 & -0.046 & -0.183 & $-0.505^{* *}$ \\
& $(0.017)$ & $(0.028)$ & $(0.123)$ & $(0.202)$ \\
Interaction with (log) real per capita GDP in source & & & 0.022 & $0.056^{* *}$ \\
economies & & Yes & Yes & Yes \\
\hline Year dummies & Yes & Yes & Yes & Yes \\
Source country FE & Yes & Yes & Yes & Yes \\
Destination country FE & Yes & Yes & Yes & Yes \\
Source-destination country FE & Yes & 293 & 861 & 293 \\
Number of observations & 861 & 0.372 & 0.403 & 0.389 \\
R-squared & 0.401 & 88 & 264 & 88 \\
Number of bilateral routes & 264 & &
\end{tabular}

$\mathrm{FE}=$ fixed effects, GDP = gross domestic product.

Notes: Similar set of regressors from the baseline model as well as a constant term are included in the estimation, but are not reported.

Standard errors in parentheses. ${ }^{* *} p<0.01,{ }^{* *} p<0.05,{ }^{*} p<0.1$.

Source: Authors' estimates. 
Overall, the nexus between economic integration and migration is complex; the direction of linkage and the strength of substitution and complementation is contingent on many other factors, including the income channel. Nonetheless, results provide empirical evidence of the overall positive and complementary influence of increasing connectedness within the region, particularly via trade, in the cross-border migration of people and labor. Meanwhile, the substitution relationship is more pronounced through the value chain links among Asian economies, thereby reducing attractiveness of leaving in search of jobs abroad.

\section{Robustness Checks}

One possible source of bias in the estimation is that the previous migrant stock may be correlated with current migration because the presence of migrant communities in the destination could encourage further movement of people from a source country. The model partly considers this network effect through dyadic variables such as colonial ties and shared language, but a concern remains that error terms may be systematically correlated across the migration routes, generating biased estimates.

To address the issue, a model is specified which uses the first differences (which refers to 5year change) in the bilateral (source-destination) migration stock, $\Delta$ Migration $_{i j t}$, as the dependent variable, following Hanson and Mclntosh (2016) and Campos (2017):

$$
\begin{gathered}
\text { Migration }_{i j t}=\alpha+\beta_{1} \text { Economic }_{i j t}+\beta_{2} \text { Demographic }_{i j t}+ \\
\beta_{3} \text { Skills }_{i j t}+\beta_{4} \text { Gravity }_{i j}+\delta_{t}+\varepsilon_{i j t}
\end{gathered}
$$

Similar regressors from equation (1) are used, except for the old-age dependency ratio in destination economies and skills gap, which like the dependent variable are also expressed as 5-year changes. Economic factors include real per capita GDP of the source country and the difference in log per capita GDP between that and destination economies. Demographic factors include log of total population in source and destination economies and the 5-year change in old-age dependency ratio in destination countries. Changes in skills gap between source and destination economies are also included. The same gravity variables are used, alongside the time dummies, $\delta_{t}$. Equation (2) is estimated using OLS, weighted by the size of the bilateral migration stock. While interpretation of the coefficients differs with that of the baseline model, it is expected to retain features of the general hypothesis on the determinants of migration.

Appendix Tables A3.1 through A3.4 present estimates of equation (2) that yield findings similar to the baseline results, although with less explanatory power given by smaller R-squared. Appendix Table A3.1 shows which of the identified factors help explain historical changes in international migration. The coefficients bear consistent signs with the baseline results, but fewer generate statistically significant estimates. Among them are the income gap, the old-age dependency ratio in destination economies, and geographical distance. In line with the baseline results in equation (1), a larger increase in migration stock is expected if the income gap widens. The income effect, which drives migration by reducing financial constraints, also seems to be at play but is inconclusive because of unstable signs observed in the two routes. The alternative model also captures how demographic transition shapes the international migration pattern. Distance remains a negative force though is generally weaker, which can be attributed to a gradual reduction in transportation and communication costs.

Meanwhile, Appendix Tables A3.2-A3.4 show results evaluating the relationship between economic integration and international migration. The general findings are consistent with baseline 
results. Both trade (Appendix Table A3.2) and FDI (Appendix Table A3.3) have overall complementary links with migratory flows through the income channel. In contrast, especially in intraAsian migration, regional production networks exert an overall substitution effect on international migration (Appendix Table A3.4).

\section{FUTURE MIGRATION FLOWS IN AND FROM ASIA AND THE PACIFIC}

\section{A. Demographic Changes and Population Aging}

Many economies in Asia and the Pacific are undergoing fundamental demographic changes that pose both opportunities and challenges to economic management. Population growth in the region continues to slow, although at a varying degree across economies. The age structure is becoming less dynamic and older. This transition is expected to accelerate and may influence migration in coming decades. The empirical exercises above highlight a pattern that holds important policy implications. Diverse demographic trends in the region should be geared toward skills complementarity in labor markets, particularly as the number of educated youths entering the workforce continues to grow in many of its developing economies.

Aging and demographic changes in some Asian economies could be a powerful accelerant of labor mobility within the region. For example, the East Asian economies present an interesting case for Asia's aging and shrinking working-age population. In the next few decades, the PRC will need more workers to compensate for an expected decline of 128.3 million in the working-age population between 2017 and 2040 (Figure 4). That decline is followed by Japan (-14.9 million), Thailand ( -7.7 million), and the Republic of Korea ( -7.5 million).

Figure 4: Changes in Working-Age Populations, 2017-2040

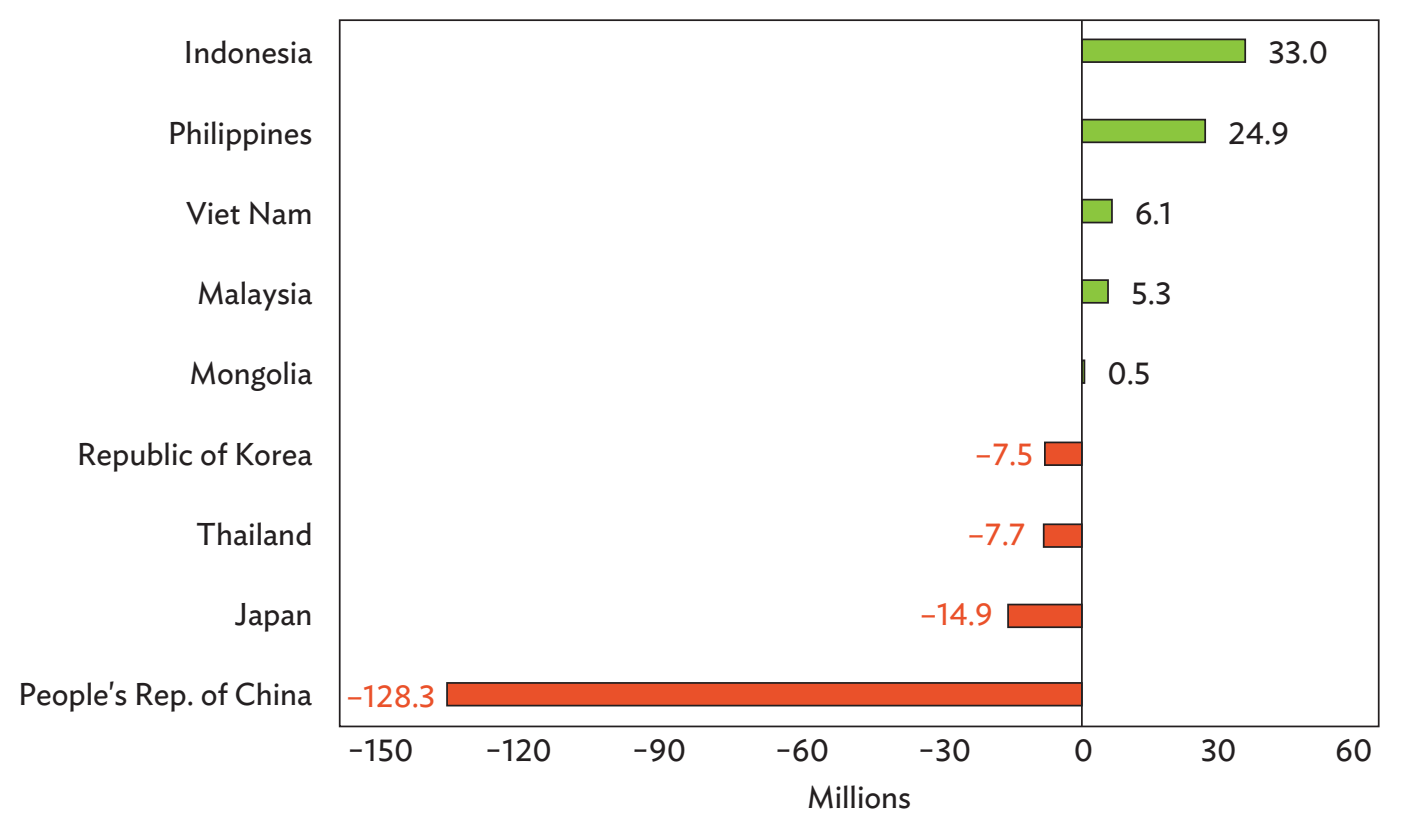

Source: ADB calculations using data from United Nations Department of Economic and Social Affairs. http://www.un.org/en/development/desa/population/ (accessed July 2018). 
On the other hand, most economies in Asia and the Pacific can expect significant increases in their working-age populations by 2030. Papua New Guinea will experience 33\% growth in available workforce, followed by the Lao People's Democratic Republic (25.1\%) and the Philippines (21.9\%). This variation in demographic transition and the speed of aging opens opportunities for more efficient allocation of the workforce through international labor migration.

As population aging progresses among Asia's developed countries, gaps such as in the supply of health-care workers are being tackled through increased migration. In Singapore, the number of foreign nurses increased nearly threefold from 3,399 in 2010 to almost 10,000 in 2016, most coming from the Philippines (Table 5). Meanwhile, Japan has announced that it will receive 10,000 care workers from Viet Nam by 2020. It is expected that migrant workers meeting the needs of aging societies will add momentum as aging progresses rapidly in many East and Southeast Asian countries.

Table 5: Registered Nurses in Singapore by Citizenship, 2010 and 2016

\begin{tabular}{lrccccc}
\hline Nationality & 2010 & Share to total & Foreign share & 2016 & Share to total & Foreign share \\
\hline Local & 18,176 & 84.2 & & 21,936 & 69.4 & \\
Foreign & 3,399 & & & 9,679 & & \\
Malaysia & 468 & 2.2 & 13.8 & 2,230 & 7.1 & 23.0 \\
PRC & 578 & 2.7 & 17.0 & 955 & 3.0 & 9.9 \\
Philippines & 1,760 & 8.2 & 51.8 & 4,942 & 15.6 & 51.1 \\
India & 220 & 1.0 & 6.5 & 544 & 1.7 & 5.6 \\
Myanmar & 165 & 0.8 & 4.9 & 742 & 2.3 & 7.7 \\
Others & 208 & 1.0 & 6.1 & 266 & 0.8 & 2.7 \\
Total & 21,575 & 100.0 & 100.0 & 31,615 & 100.0 & 100.0 \\
\hline
\end{tabular}

PRC = People's Republic of China.

Source: Singapore Nursing Board, Annual Reports for 2010 and 2016.

\section{B. International Migration of the Skilled Workforce}

Our estimation results suggest that the improvement in human capital in Asia and the Pacific, by narrowing the skills gap with major destination economies in and outside the region, can lead to more cross-border migration. This suggests that there will be a greater flow of skilled migrants from and within the region as education attainment gaps are rapidly closing between major origin and destination economies, even in a short span of time (Figure 5).

Labor mobility will provide valuable opportunities, particularly for an educated workforce, to acquire on-the-job skills training and experience in locations that may enjoy more advanced technologies. Enhanced skills mobility will also help address youth unemployment and underutilization of skills that are frequently observed in developing countries. Policies that promote portability of skills (such as mutual recognition of qualification and certification) can facilitate the movement of talent. 
Figure 5: Educational Attainment of Working-Age Population

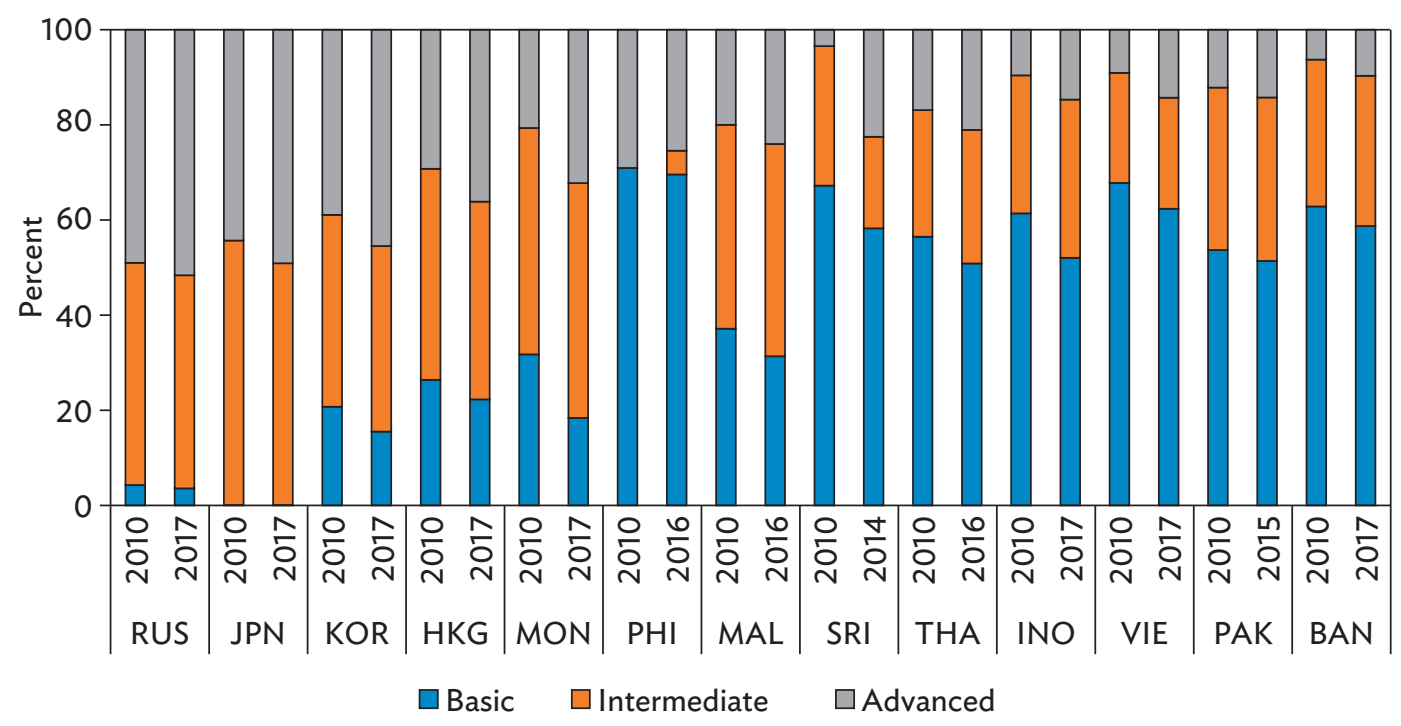

BAN = Bangladesh; $\mathrm{HKG}=$ Hong Kong, China; $\mathrm{INO}=$ Indonesia; JPN = Japan; KOR = Republic of Korea; $M A L=$ Malaysia; $M O N=$ Mongolia; PAK = Pakistan; PHI = Philippines; RUS = Russian Federation; SRI = Sri Lanka; THA = Thailand; and VIE = Viet Nam. Source: ADB calculations using data from International Labour Organization. ILOSTAT. https://www.ilo.org/ilostat/ (accessed 7 August 2018).

\section{CONCLUSIONS AND POLICY IMPLICATIONS}

International migrants from Asia and the Pacific still account for the largest share of the global movement of people and labor. It is apparent, though, that movement is shifting more and more toward other regions, particularly the Middle East, consequently narrowing the share of intra-Asia migration.

The paper identifies and validates key driving forces of international migration from and within the region. We find that economic factors prompt the movement of people in two tracks. The widening income gap between the source and destination economies tend to drive more migration, while rising income in the source countries reduces financial constraint for choosing the migration option. Migration flows also gravitate more toward destinations that present lower direct and indirect (social, cultural, and psychological) costs of relocation. The growing share of older population in destination economies and the similarities in the level of educational attainment are also found associated with greater movement.

Our empirical results provide interesting insights on how economic integration shapes the cross-border movement of people and labor from the region. Deeper trade, investment, and production ties between countries could substitute cross-border migration within the region. However, the corresponding increase in income and related economic opportunities in source economies resulting from deepening economic integration could eventually induce or complement cross-border migration, possibly by relaxing the financial constraints on such movements.

Ultimately, questions about the net effect of economic integration on cross-border labor movement can be tackled empirically. Meanwhile, economic benefits from regional cooperation and 
integration offer broader choices for citizens to maximize their welfare. Further studies are also needed to explain the impact of cross-border labor mobility on economic opportunities and growth. From a policy viewpoint, given the political sensitivity of international migration, it is important to understand the impact of trade and investment on employment, both in source and destination economies.

Further, consistent with the migration literature, demographic variables go a long way to explaining the movement of people and labor. Among them, the aging populations of prominent destination economies tend to be associated with higher immigration, which could be explained by shortage of labor and skills, among other factors. This finding may be very relevant for Asia and the Pacific in as much as the diversity of demographic trends across the region could be leveraged toward skills complementarity in labor markets. As such, the region's economies should work together on a regional policy that could encourage better allocation of labor and skills.

Asia and the Pacific stands to gain from reducing hurdles to the interregional migration of talent, moving away from being an area of net emigration of skilled workers. Promoting the portability of skills through skills recognition schemes and creating a business environment friendly to entrepreneurs and investors can facilitate this process. Increased business and academic dialogue and tourism can also contribute to removing cultural and language barriers that in some areas are persistent. The gains are potentially large in promoting skilled labor mobility and migration, receiving limited encouragement and promotion to date. 


\section{APPENDIX}

Table A1: Generalized Estimating Equation Estimates of the Gravity Model of Migration

\begin{tabular}{|c|c|c|}
\hline \multirow[b]{2}{*}{ Variables } & \multicolumn{2}{|c|}{ GEE } \\
\hline & Route 1 & Route 2 \\
\hline \multicolumn{3}{|l|}{ Economic factors } \\
\hline Income gap between source and destination economies & $\begin{array}{l}0.247^{* * *} \\
(0.067)\end{array}$ & $\begin{array}{r}0.586^{* * *} \\
(0.114)\end{array}$ \\
\hline Real per capita GDP in source economies, in logs & $\begin{array}{l}0.291^{* * *} \\
(0.083) \\
\end{array}$ & $\begin{array}{l}0.811^{* * *} \\
(0.152)\end{array}$ \\
\hline \multicolumn{3}{|l|}{ Demographic factors } \\
\hline Total population in destination economies, in logs & $\begin{array}{l}1.103^{* * *} \\
(0.122)\end{array}$ & $\begin{array}{l}1.962^{* * *} \\
(0.464)\end{array}$ \\
\hline Total population in source economies, in logs & $\begin{array}{r}-0.393^{* *} \\
(0.172)\end{array}$ & $\begin{array}{l}-0.284 \\
(0.307)\end{array}$ \\
\hline Old-age dependency ratio in destination economies & $\begin{array}{r}0.055^{* * *} \\
(0.005)\end{array}$ & $\begin{array}{l}0.065^{* * *} \\
(0.009)\end{array}$ \\
\hline \multicolumn{3}{|l|}{ Skills complementarity } \\
\hline $\begin{array}{l}\text { Gap between source and destination economies in average years of } \\
\text { schooling }\end{array}$ & $\begin{array}{r}-0.587^{* * *} \\
(0.105)\end{array}$ & $\begin{array}{r}-0.950^{* * *} \\
(0.165)\end{array}$ \\
\hline \multicolumn{3}{|l|}{ Gravity variables } \\
\hline Distance between capitals, in logs & $\begin{array}{c}-1.512^{* * *} \\
(0.148)\end{array}$ & $\begin{array}{r}-1.366^{* * *} \\
(0.241)\end{array}$ \\
\hline Contiguity & $\begin{array}{l}1.215^{* * *} \\
(0.328)\end{array}$ & $\begin{array}{l}0.928^{* *} \\
(0.385)\end{array}$ \\
\hline Common official or primary language & $\begin{array}{l}0.565^{* *} \\
(0.247)\end{array}$ & $\begin{array}{r}0.606^{*} \\
(0.350)\end{array}$ \\
\hline Colonial relationship & $\begin{array}{c}2.790^{* * *} \\
(0.288)\end{array}$ & $\begin{array}{r}1.674^{*} \\
(1.002)\end{array}$ \\
\hline Constant & $\begin{array}{r}10.253^{* * *} \\
(3.578)\end{array}$ & $\begin{array}{l}-11.143 \\
(8.441)\end{array}$ \\
\hline Year dummies & Yes & Yes \\
\hline Source country FE & Yes & Yes \\
\hline Destination country FE & Yes & Yes \\
\hline Observations & 2,276 & 816 \\
\hline Number of bilateral routes & 433 & 147 \\
\hline
\end{tabular}

$\mathrm{FE}=$ fixed effects, $\mathrm{GDP}$ = gross domestic product, $\mathrm{GEE}=$ generalized estimating equation. Notes: Standard errors in parentheses. ${ }^{* *} p<0.01,{ }^{* *} p<0.05,{ }^{*} p<0.1$.

Source: Authors' estimates. 


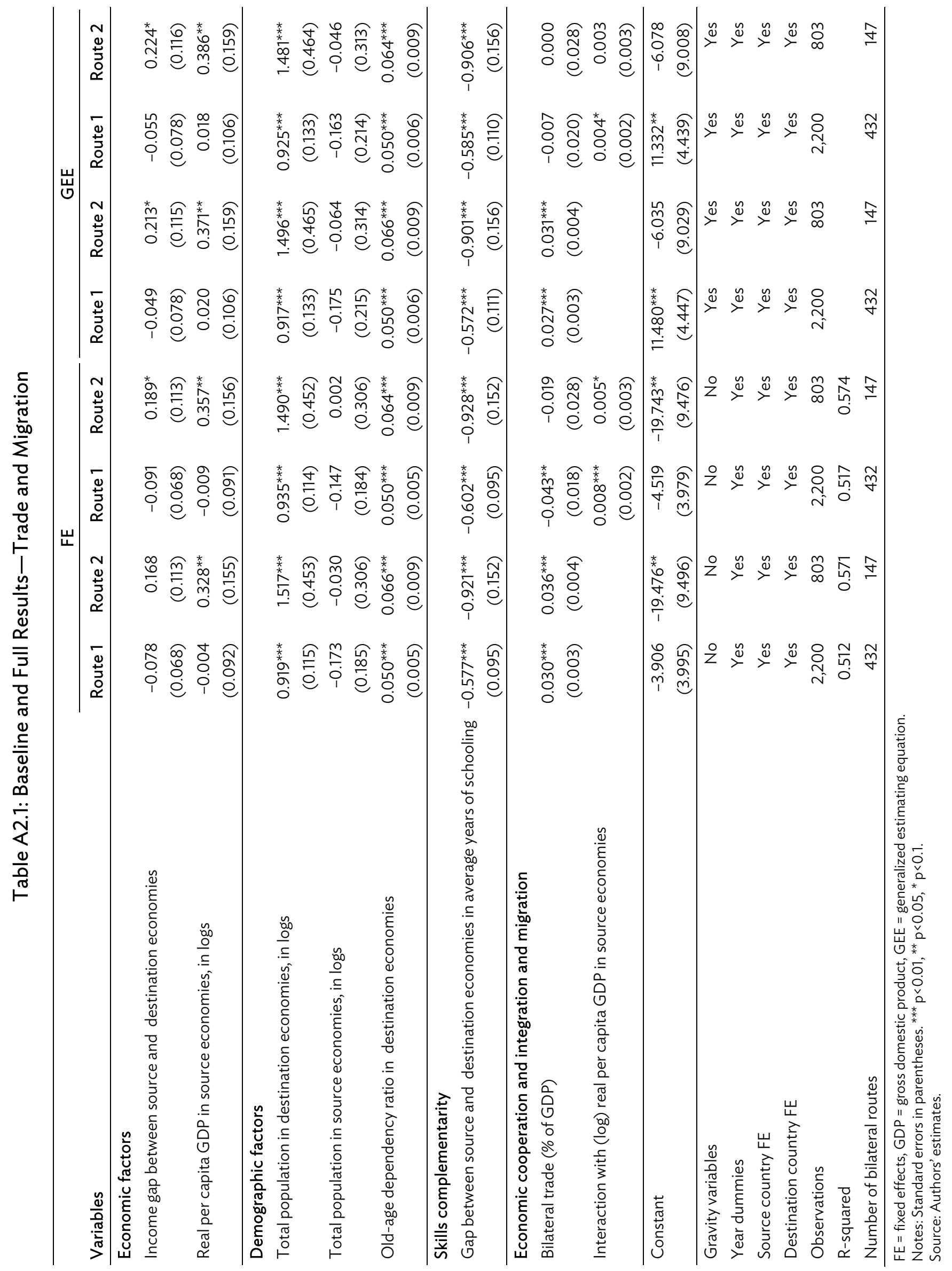




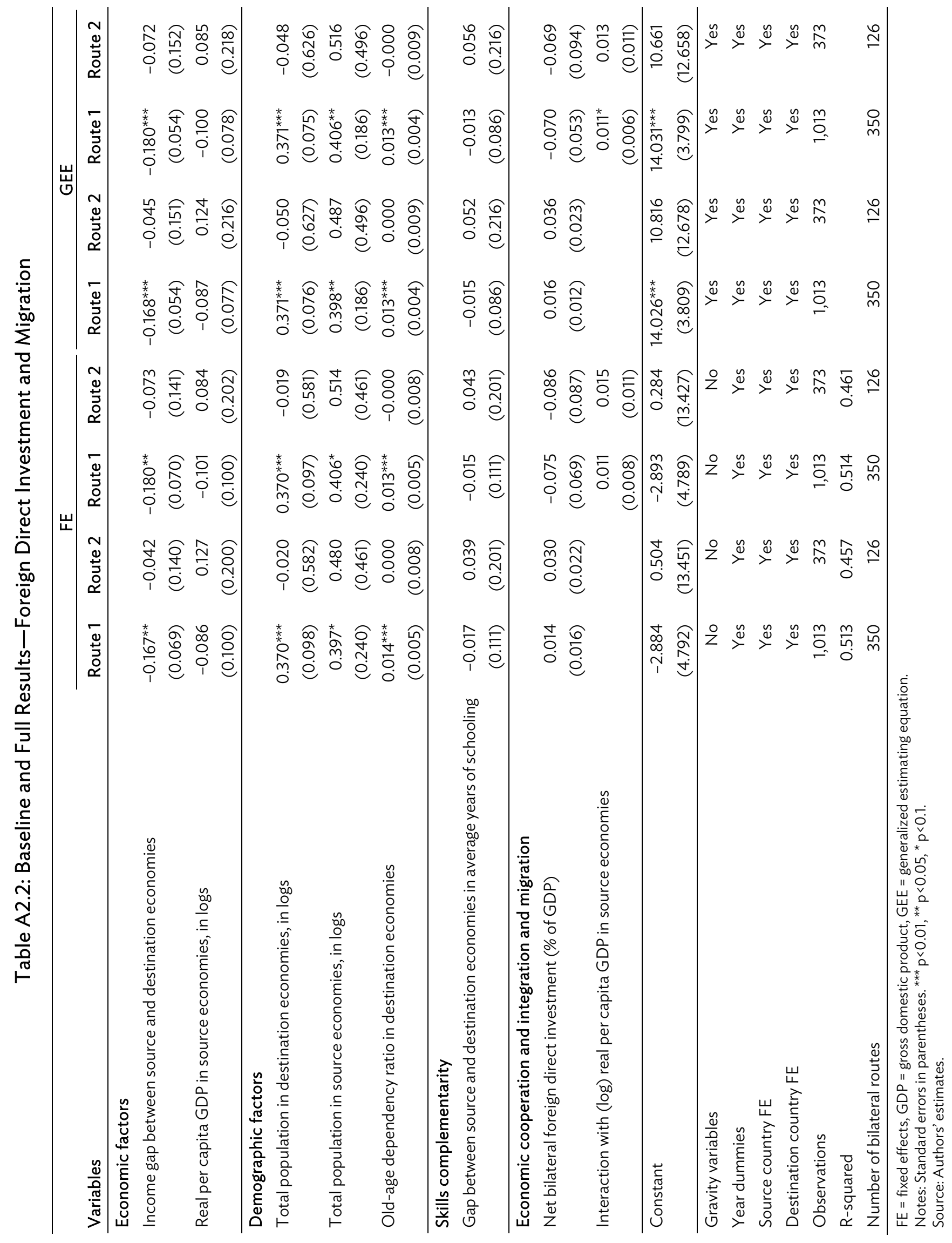




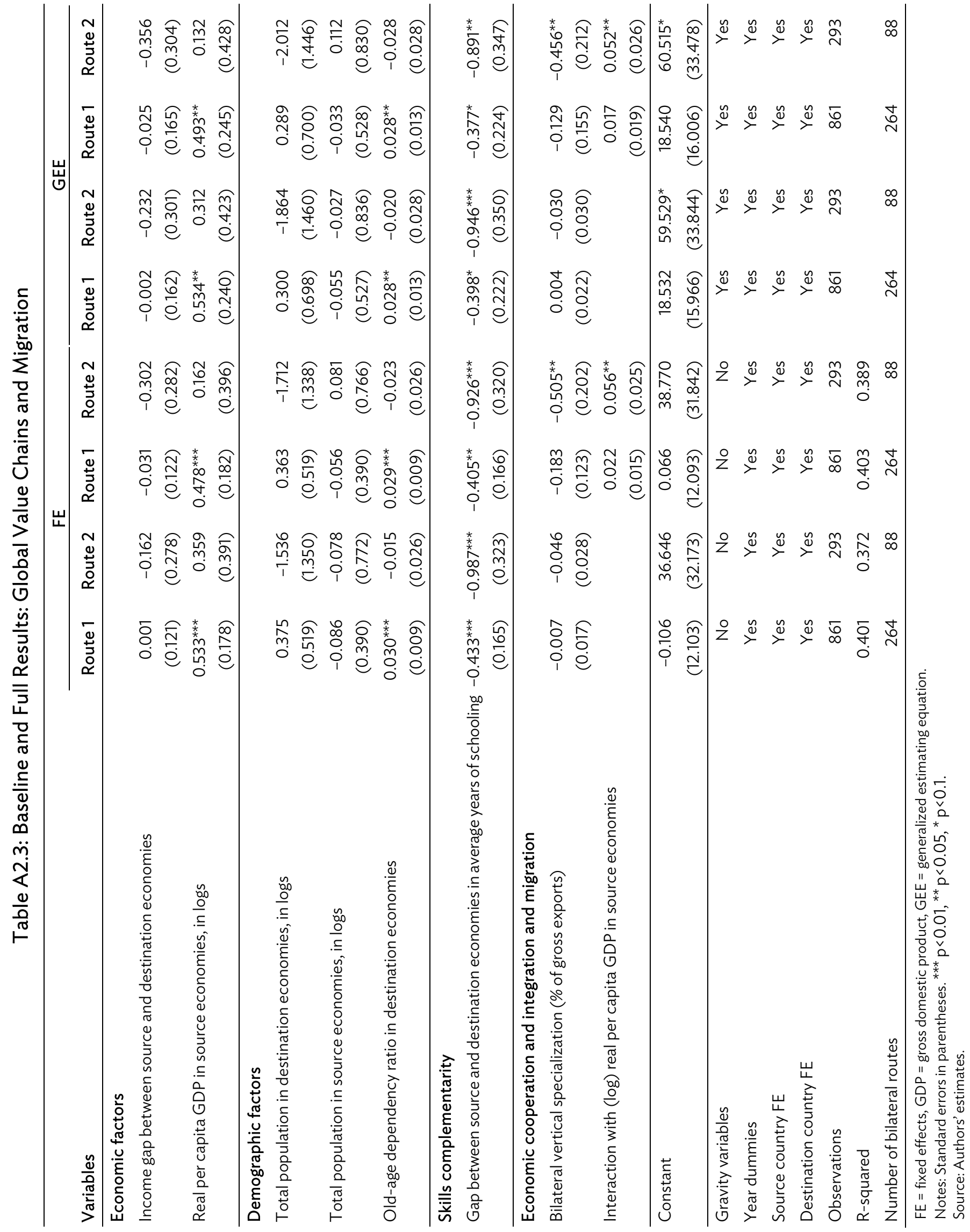


Table A3.1: Robustness-Determinants of Migration

\begin{tabular}{lrr}
\hline Variables & Route 1 & Route 2 \\
\hline Economic factors & & \\
Income gap between source and destination economies & $0.057^{* * *}$ & 0.008 \\
& $(0.019)$ & $(0.032)$ \\
Real per capita GDP in source economies, in logs & 0.011 & -0.022 \\
& $(0.022)$ & $(0.028)$ \\
\hline Demographic factors & & \\
Total population in destination economies, in logs & 0.006 & 0.042 \\
& $(0.010)$ & $(0.026)$ \\
Total population in source economies, in logs & -0.006 & $-0.025^{* *}$ \\
& $(0.006)$ & $(0.010)$ \\
5-year change in old-age dependency ratio in destination & $0.278^{* * *}$ & $0.987^{* * *}$ \\
economies & $(0.080)$ & $(0.273)$ \\
\hline Skills complementarity & & \\
5-year change in skills gap between source and destination & -0.137 & -0.160 \\
economies & $(0.174)$ & $(0.291)$ \\
\hline Gravity variables & & \\
Distance between capitals, in logs & & \\
R-squared & $-0.056^{* *}$ & 0.012 \\
\hline Contiguity & $(0.023)$ & $(0.040)$ \\
Common official or primary language & -0.064 & -0.034 \\
\hline Year dummies & $(0.044)$ & $(0.064)$ \\
Observations & -0.010 & -0.007 \\
& $(0.025)$ & $(0.076)$ \\
& $-0.169^{* * *}$ & $-0.440^{* * *}$ \\
& $(0.034)$ & $(0.101)$ \\
\hline & $0.514^{* *}$ & 0.026 \\
& $(0.214)$ & $(0.702)$ \\
\hline
\end{tabular}

$\mathrm{GDP}=$ gross domestic product.

Notes: Robust standard errors in parentheses. ${ }^{* *} p<0.01,{ }^{* *} p<0.05,{ }^{*} p<0.1$.

Source: Authors' estimates. 
Table A3.2: Robustness-Trade and Migration

\begin{tabular}{|c|c|c|c|c|}
\hline \multirow[b]{2}{*}{ Variables } & \multicolumn{2}{|c|}{ Model 1} & \multicolumn{2}{|c|}{ Model 2} \\
\hline & Route 1 & Route 2 & Route 1 & Route 2 \\
\hline \multicolumn{5}{|l|}{ Economic factors } \\
\hline \multirow[t]{2}{*}{ Income gap between source and destination economies } & $0.052^{* * *}$ & 0.014 & $0.059^{* * *}$ & 0.024 \\
\hline & $(0.020)$ & $(0.029)$ & $(0.019)$ & $(0.028)$ \\
\hline \multirow[t]{2}{*}{ Real per capita GDP in source economies, in logs } & 0.006 & -0.037 & -0.001 & -0.042 \\
\hline & $(0.022)$ & $(0.028)$ & $(0.024)$ & $(0.029)$ \\
\hline \multicolumn{5}{|l|}{ Demographic factors } \\
\hline \multirow[t]{2}{*}{ Total population in destination economies, in logs } & -0.002 & 0.006 & 0.002 & 0.007 \\
\hline & $(0.011)$ & $(0.016)$ & $(0.011)$ & $(0.016)$ \\
\hline \multirow[t]{2}{*}{ Total population in source economies, in logs } & 0.002 & -0.008 & -0.001 & -0.013 \\
\hline & $(0.007)$ & $(0.010)$ & $(0.007)$ & $(0.010)$ \\
\hline \multirow{2}{*}{$\begin{array}{l}\text { 5-year change in old-age dependency ratio in destination } \\
\text { economies }\end{array}$} & $0.265^{* * *}$ & $0.801^{* * *}$ & $0.275^{* * *}$ & $0.811^{* * *}$ \\
\hline & $(0.073)$ & $(0.249)$ & $(0.074)$ & $(0.246)$ \\
\hline \multicolumn{5}{|l|}{ Skills complementarity } \\
\hline \multirow{2}{*}{$\begin{array}{l}5 \text {-year change in skills gap between source and destination } \\
\text { economies }\end{array}$} & -0.112 & -0.151 & -0.062 & -0.071 \\
\hline & $(0.164)$ & $(0.273)$ & $(0.159)$ & $(0.275)$ \\
\hline \multicolumn{5}{|l|}{ Economic cooperation and integration and migration } \\
\hline \multirow[t]{2}{*}{ Bilateral trade (\% of GDP) } & $0.004^{*}$ & $0.005^{*}$ & -0.009 & -0.007 \\
\hline & $(0.002)$ & $(0.003)$ & $(0.007)$ & $(0.009)$ \\
\hline \multirow[t]{2}{*}{ Interaction with real per capita GDP in source economies } & & & 0.001 & 0.001 \\
\hline & & & $(0.001)$ & $(0.001)$ \\
\hline \multirow[t]{2}{*}{ Constant } & $0.450^{* *}$ & 0.597 & $0.532^{* *}$ & 0.775 \\
\hline & $(0.213)$ & $(0.553)$ & $(0.215)$ & $(0.547)$ \\
\hline Gravity variables & Yes & Yes & Yes & Yes \\
\hline Year dummies & Yes & Yes & Yes & Yes \\
\hline Observations & 1,861 & 671 & 1,861 & 671 \\
\hline R-squared & 0.233 & 0.312 & 0.237 & 0.318 \\
\hline
\end{tabular}

GDP = gross domestic product.

Notes: Robust standard errors in parentheses. ${ }^{* *} p<0.01,{ }^{* *} p<0.05,{ }^{*} p<0.1$.

Source: Authors' estimates. 


\section{Table A3.3: Robustness-Foreign Direct Investment and Migration}

\begin{tabular}{|c|c|c|c|c|}
\hline \multirow[b]{2}{*}{ Variables } & \multicolumn{2}{|c|}{ Model 1} & \multicolumn{2}{|c|}{ Model 2} \\
\hline & Route 1 & Route 2 & Route 1 & Route 2 \\
\hline \multicolumn{5}{|l|}{ Economic factors } \\
\hline Income gap between source and destination economies & $\begin{array}{r}0.009 \\
(0.027)\end{array}$ & $\begin{array}{r}-0.010 \\
(0.046)\end{array}$ & $\begin{array}{r}0.014 \\
(0.026)\end{array}$ & $\begin{array}{l}-0.006 \\
(0.048)\end{array}$ \\
\hline Real per capita GDP in source economies, in logs & $\begin{array}{r}-0.043^{* *} \\
(0.022)\end{array}$ & $\begin{array}{l}-0.050 \\
(0.036)\end{array}$ & $\begin{array}{r}-0.047^{* *} \\
(0.022)\end{array}$ & $\begin{array}{l}-0.053 \\
(0.037)\end{array}$ \\
\hline \multicolumn{5}{|l|}{ Demographic factors } \\
\hline Total population in destination economies, in logs & $\begin{array}{r}-0.022^{* *} \\
(0.011)\end{array}$ & $\begin{array}{r}0.046 \\
(0.033)\end{array}$ & $\begin{array}{r}-0.021^{* *} \\
(0.011)\end{array}$ & $\begin{array}{r}0.041 \\
(0.037)\end{array}$ \\
\hline Total population in source economies, in logs & $\begin{array}{r}0.001 \\
(0.007)\end{array}$ & $\begin{array}{l}-0.022 \\
(0.014)\end{array}$ & $\begin{array}{r}0.002 \\
(0.007)\end{array}$ & $\begin{array}{l}-0.021 \\
(0.014)\end{array}$ \\
\hline $\begin{array}{l}\text { 5-year change in old-age dependency ratio in destination } \\
\text { economies }\end{array}$ & $\begin{array}{r}0.277^{* * *} \\
(0.073)\end{array}$ & $\begin{array}{c}0.775^{* * *} \\
(0.299)\end{array}$ & $\begin{array}{r}0.282^{* * *} \\
(0.071)\end{array}$ & $\begin{array}{l}0.759^{* *} \\
(0.308)\end{array}$ \\
\hline \multicolumn{5}{|l|}{ Skills complementarity } \\
\hline $\begin{array}{l}5 \text {-year change in skills gap between source and destination } \\
\text { economies }\end{array}$ & $\begin{array}{r}-0.167 \\
(0.245)\end{array}$ & $\begin{array}{l}-0.434 \\
(0.327)\end{array}$ & $\begin{array}{r}-0.115 \\
(0.237)\end{array}$ & $\begin{array}{l}-0.409 \\
(0.344)\end{array}$ \\
\hline \multicolumn{5}{|l|}{ Economic cooperation and integration and migration } \\
\hline Net bilateral foreign direct investment (\% of GDP) & $\begin{array}{r}0.041^{* * *} \\
(0.013)\end{array}$ & $\begin{array}{l}0.021^{* *} \\
(0.010)\end{array}$ & $\begin{array}{l}-0.052 \\
(0.043)\end{array}$ & $\begin{array}{r}-0.016 \\
(0.050)\end{array}$ \\
\hline Interaction with real per capita GDP in source economies & & & $\begin{array}{r}0.012^{*} \\
(0.006)\end{array}$ & $\begin{array}{r}0.005 \\
(0.007)\end{array}$ \\
\hline Constant & $\begin{array}{l}1.119^{* * *} \\
(0.290)\end{array}$ & $\begin{array}{r}0.213 \\
(0.859) \\
\end{array}$ & $\begin{array}{l}1.133^{* * *} \\
(0.292)\end{array}$ & $\begin{array}{r}0.358 \\
(0.976)\end{array}$ \\
\hline Gravity variables & Yes & Yes & Yes & Yes \\
\hline Year dummies & Yes & Yes & Yes & Yes \\
\hline Observations & 982 & 367 & 982 & 367 \\
\hline R-squared & 0.278 & 0.284 & 0.283 & 0.285 \\
\hline
\end{tabular}

$\mathrm{GDP}=$ gross domestic product.

Notes: Robust standard errors in parentheses. ${ }^{* *} p<0.01,{ }^{* *} p<0.05,{ }^{*} p<0.1$.

Source: Authors' estimates. 
Table A3.4: Robustness-Global Value Chains and Migration

\begin{tabular}{|c|c|c|c|c|}
\hline \multirow[b]{2}{*}{ Variables } & \multicolumn{2}{|c|}{ Model 1} & \multicolumn{2}{|c|}{ Model 2} \\
\hline & Route 1 & Route 2 & Route 1 & Route 2 \\
\hline \multicolumn{5}{|l|}{ Economic factors } \\
\hline \multirow[t]{2}{*}{ Income gap between source and destination economies } & 0.019 & 0.030 & 0.016 & 0.049 \\
\hline & $(0.031)$ & $(0.055)$ & $(0.031)$ & $(0.056)$ \\
\hline \multirow[t]{2}{*}{ Real per capita GDP in source economies, in logs } & -0.018 & -0.015 & -0.017 & -0.029 \\
\hline & $(0.033)$ & $(0.057)$ & $(0.034)$ & $(0.058)$ \\
\hline \multicolumn{5}{|l|}{ Demographic factors } \\
\hline \multirow[t]{2}{*}{ Total population in destination economies, in logs } & -0.002 & -0.040 & -0.002 & -0.038 \\
\hline & $(0.019)$ & $(0.037)$ & $(0.019)$ & $(0.037)$ \\
\hline \multirow[t]{2}{*}{ Total population in source economies, in logs } & 0.004 & -0.002 & 0.004 & -0.003 \\
\hline & $(0.007)$ & $(0.015)$ & $(0.007)$ & $(0.015)$ \\
\hline \multirow{2}{*}{$\begin{array}{l}\text { 5-year change in old-age dependency ratio in destination } \\
\text { economies }\end{array}$} & $0.435^{*}$ & 1.111 & $0.451^{*}$ & $1.324^{*}$ \\
\hline & $(0.245)$ & $(0.719)$ & $(0.238)$ & $(0.728)$ \\
\hline \multicolumn{5}{|l|}{ Skills complementarity } \\
\hline \multirow{2}{*}{$\begin{array}{l}\text { 5-year change in skills gap between source and destination } \\
\text { economies }\end{array}$} & -0.163 & -0.112 & -0.178 & 0.073 \\
\hline & $(0.244)$ & $(0.379)$ & $(0.250)$ & $(0.365)$ \\
\hline \multicolumn{5}{|l|}{ Economic cooperation and integration and migration } \\
\hline \multirow[t]{2}{*}{ Bilateral vertical specialization (\% of gross exports) } & -0.009 & -0.013 & 0.005 & $-0.184^{*}$ \\
\hline & $(0.011)$ & $(0.017)$ & $(0.033)$ & $(0.099)$ \\
\hline \multirow[t]{2}{*}{ Interaction with real per capita GDP in source economies } & & & -0.002 & $0.019^{*}$ \\
\hline & & & $(0.004)$ & $(0.011)$ \\
\hline \multirow[t]{2}{*}{ Constant } & 0.599 & 1.639 & 0.593 & 1.626 \\
\hline & $(0.450)$ & $(1.067)$ & $(0.453)$ & $(1.060)$ \\
\hline Gravity variables & Yes & Yes & Yes & Yes \\
\hline Year dummies & Yes & Yes & Yes & Yes \\
\hline Observations & 834 & 288 & 834 & 288 \\
\hline R-squared & 0.205 & 0.328 & 0.205 & 0.337 \\
\hline
\end{tabular}

GDP = gross domestic product.

Notes: Robust standard errors in parentheses. ${ }^{* *} p<0.01,{ }^{* *} p<0.05,{ }^{*} p<0.1$.

Source: Authors' estimates. 


\section{REFERENCES}

Aroca, Patricio, and William F. Maloney. 2005. "Migration, Trade, and Foreign Direct Investment in Mexico." The World Bank Economic Review 19 (3): 449-72.

Asian Development Bank (ADB). 2018. Asian Economic Integration Report 2018. Manila.

Bahar, Dany, and Hillel Rapoport. 2018. "Migration, Knowledge Diffusion and the Comparative Advantage of Nations." The Economic Journal 128 (612): F273-F305.

Barro, Robert, and Jong-Wha Lee. 2013. "A New Data Set of Educational Attainment in the World, 1950-2010.” Journal of Development Economics 104: 184-98.

- 2015. Education Matters: Global Schooling Gains from the 19th to the 21st Century. New York: Oxford University Press.

Campos, Rodolfo G. 2017. “International Migration Pressures in the Long Run.” Banco de España Working Paper No. 1734. Madrid: Banco de España.

Clemens, Michael A. 2014. "Does Development Reduce Migration?" International Handbook on Migration and Economic Development, edited by Robert E.B. Lucas, 152-85. Cheltenham, UK: Edward Elgar.

Cui, James, and Guoqi Qian. 2007. "Selection of Working Correlation Structure and Best Model in GEE Analyses of Longitudinal Data." Communications in Statistics-Simulation and Computation 36 (5): 987-96.

Dao, Thu Hien, Frédéric Docquier, Mathilde Maureld, and Pierre Schaus. 2018. "Global Migration in the Twentieth and Twenty-First Centuries: The Unstoppable Force of Demography." FERDI Working Paper No. 223. Clermont-Ferrand, France: FERDI.

De Simone, Gianfranco, and Miriam Manchin. 2012. "Outward Migration and Inward FDI: Factor Mobility between Eastern and Western Europe." Review of International Economics 20 (3): 600-15.

Ducanes, Geoffrey, and Manolo Abella. 2008. “Labour Shortage Responses in Japan, Korea, Singapore, Hong Kong, and Malaysia: A Review and Evaluation." ILO Asian Regional Programme on Governance of Labour Migration Working Paper No. 2. Bangkok: International Labour Organization.

Gould, David M. 1994. "Immigrant Links to the Home Country: Empirical Implications for US Bilateral Trade Flows." Review of Economics and Statistics 76 (2): 302-16.

Hanley, James A., Abdissa Negassa, Michael D. deB. Edwardes, and Janet E. Forrester. 2003. "Statistical Analysis of Correlated Data Using Generalized Estimating Equations: An Orientation." American Journal of Epidemiology 157 (4): 364-75.

Hanson, Gordon H. 2008. "International Migration and Development." Commission on Growth and Development Working Paper No. 42. Washington DC: World Bank. 
Hanson, Gordon H., and Craig Mclntosh. 2016. "Is the Mediterranean the New Rio Grande? US and EU Immigration Pressures in the Long Run.” Journal of Economic Perspectives 30 (4): 57-82.

Horrocks, Julie. 1997. "Generalized Linear Models.” (Generalized Estimating Equations, Notes from a workshop, Manitoba Centre for Health Policy (MCHP), Winnipeg, Manitoba, Canada. 5 January.

International Labour Organization. ILOSTAT. https://www.ilo.org/ilostat/.

2015. ILO Global Estimates on Migrant Workers. Geneva. https:/www.ilo.org/wcmsp5/ groups/public/---dgreports/---dcomm/documents/publication/wcms_436343.pdf.

Kim, Keuntae, and Joel E. Cohen. 2010. "Determinants of International Migration Flows to and from Industrialized Countries: A Panel Data Approach Beyond Gravity.” International Migration Review 44 (4): 899-932.

Kugler, Maurice, and Hillel Rapoport. 2011. "Migration, FDI and the Margins of Trade.” CID Working Paper No. 222. Cambridge, MA: Center for International Development, Harvard University.

Martin, Philip L., and J. Edward Taylor. 1996. "The Anatomy of a Migration Hump." In Development Strategy, Employment, and Migration: Insights from Models, edited by J. Edward Taylor, 43-62. Paris: Organization for Economic Cooperation and Development.

Massey, Douglas S., and Rene M. Zenteno. 1999. "The Dynamics of Mass Migration." Proceedings of the National Academy of Sciences 96 (9): 5328-35.

McKenzie, David, and Hillel Rapoport. 2010. "Self-Selection Pattern in Mexico-US Migration: The Role of Migration Networks." The Review of Economics and Statistics 92 (4): 811-21.

Nakata, H. 2017. "Attitudes Towards Immigration in an Ageing Society: Evidence from Japan.” RIETI Discussion Paper 17-E-095. Tokyo: Research Institute on Economy, Trade and Industry.

Ruhs, Martin. 2018. "Labor Immigration Policies in High-income Countries: Variations across Political Regimes and Varieties of Capitalism." The Journal of Legal Studies. 47 (S1): S89-S127.

Sauvant Karl P., Padma Mallampally, and Persephone Economou. 1993. "Foreign Direct Investment and International Migration." Transnational Corporations 2 (1): 33-69.

Shin, Gi-Wook, and Rennie J. Moon. 2018. "From Brain Drain to Brain Circulation and Linkage." Shorenstein Asia-Pacific Research Center Working Paper. Stanford, CA: Stanford University. https://fsi-live.s3.us-west-1.amazonaws.com/s3fs-public/brain_drain_to_circulation_and_ linkage_0.pdf.

Stark, Oded, Christian Helmenstein, and Alexia Prskawetz. 1998. "Human Capital Depletion, Human Capital Formation, and Migration: A Blessing or a "Curse"? Economics Letters 60 (3): 363-67.

Tomohara, Akinori. 2017. "Does Immigration Crowd Out Foreign Direct Investment Inflows? Tradeoff between Contemporaneous FDI-Immigration Substitution and Ethnic Network Externalities." Economic Modelling 64: 40-47. 
UNHCR Population Statistics. http://popstats.unhcr.org/en/overview\#_ga=2.171769312.1130396316 .1531288354-34172564.1531288354.

United Nations. 1998. Recommendations on Statistics of International Migration Revision 1. New York.

United Nations, Department of Economic and Social Affairs. http://www.un.org/en/development/ desa/population/.

_. International Migrant Stock: The 2017 Revision. http://www.un.org/en/development/desa/ population/migration/data/estimates2/estimates17.shtml.

World Bank. 2018. "Moving for Global Prosperity: Global Migration and Labor Markets." Policy Research Report. Washington, DC.

Zaiceva, Anzelika, and Klaus F. Zimmermann. 2014. "Migration and the Demographic Shift." IZA Discussion Papers No. 8743. Bonn: IZA Institute of Labor Economics. 


\section{International Migration in Asia and the Pacific}

Determinants and Role of Economic Integration

International migration is an essential element of economic integration. This paper examines key factors driving the movement of people from and within Asia and the Pacific. Its analysis of bilateral international migrant stock data predicts a large volume of bilateral migration if there is a wider income gap between host and source countries or a growing share of older people in host economies. It finds that cross-border migration helps foster economic ties, especially through trade and value chain linkages. The region stands to gain from its diverse demographic profiles, as more countries transition to skills-based and knowledge-intensive economies.

\section{About the Asian Development Bank}

ADB is committed to achieving a prosperous, inclusive, resilient, and sustainable Asia and the Pacific, while sustaining its efforts to eradicate extreme poverty. Established in 1966, it is owned by 68 members -49 from the region. Its main instruments for helping its developing member countries are policy dialogue, loans, equity investments, guarantees, grants, and technical assistance. 